\title{
Ultramafic Alkaline Rocks of Kepino Cluster, Arkhangelsk, Russia: Different Evolution of Kimberlite Melts in Sills and Pipes
}

\author{
Alexey Vladimirovich Kargin 1,2*(D), Anna Andreevna Nosova ${ }^{1,2}$, Ludmila Vyacheslavovna Sazonova 1,2,3, \\ Vladimir Vasilievich Tretyachenko ${ }^{4}$, Yulia Olegovna Larionova ${ }^{1}$ and Elena Vladimirovna Kovalchuk ${ }^{1}$ \\ 1 Institute of Geology of Ore Deposits, Petrography, Mineralogy and Geochemistry Russian Academy of \\ Sciences (IGEM RAS), 119017 Moscow, Russia; nosova@igem.ru (A.A.N.); sazonovalv52@mail.ru (L.V.S.); \\ ukalarionova@gmail.com (Y.O.L.); elena7kovalchuk@gmail.com (E.V.K.) \\ 2 Vernadsky Institute of Geochemistry and Analytical Chemistry (GEOKhI), 119334 Moscow, Russia \\ 3 Geology Department, Lomonosov Moscow State University, 119991 Moscow, Russia \\ 4 Vilyui GRE AC ALROSA, 163000 Arkhangelsk, Russia; tretyachenkovv@severalmaz.alrosa.ru \\ * Correspondence: kargin-igem@mail.ru; Tel.: +7-4992308243
}

check for

updates

Citation: Kargin, A.V.; Nosova, A.A.; Sazonova, L.V.; Tretyachenko, V.V.; Larionova, Y.O.; Kovalchuk, E.V. Ultramafic Alkaline Rocks of Kepino Cluster, Arkhangelsk, Russia: Different Evolution of Kimberlite Melts in Sills and Pipes. Minerals 2021, 11, 540. https://doi.org/ $10.3390 / \min 11050540$

Academic Editor: Paolo Nimis

Received: 17 April 2021

Accepted: 16 May 2021

Published: 19 May 2021

Publisher's Note: MDPI stays neutral with regard to jurisdictional claims in published maps and institutional affiliations.

Copyright: (c) 2021 by the authors. Licensee MDPI, Basel, Switzerland. This article is an open access article distributed under the terms and conditions of the Creative Commons Attribution (CC BY) license (https:// creativecommons.org/licenses/by/ $4.0 /)$.

\begin{abstract}
To provide new insights into the evolution of kimberlitic magmas, we have undertaken a detailed petrographic and mineralogical investigation of highly evolved carbonate-phlogopitebearing kimberlites of the Kepino cluster, Arkhangelsk kimberlite province, Russia. The Kepino kimberlites are represented by volcanoclastic breccias and massive macrocrystic units within pipes as well as coherent porphyritic kimberlites within sills. The volcanoclastic units from pipes are similar in petrography and mineral composition to archetypal (Group 1) kimberlite, whereas the sills represent evolved kimberlites that exhibit a wide variation in amounts of carbonate and phlogopite. The latestage evolution of kimberlitic melts involves increasing oxygen fugacity and fluid-phase evolution (forming carbonate segregations by exsolution, etc.). These processes are accompanied by the transformation of primary Al- and Ti-bearing phlogopite toward tetraferriphlogopite and the transition of spinel compositions from magmatic chromite to magnesian ulvöspinel and titanomagnetite. Similar primary kimberlitic melts emplaced as sills and pipes may be transitional to carbonatite melts in the shallow crust. The kimberlitic pipes are characterised by low carbonate amounts that may reflect the fluid degassing process during an explosive emplacement of the pipes. The Kepino kimberlite age, determined as $397.3 \pm 1.2 \mathrm{Ma}$, indicates two episodes of ultramafic alkaline magmatism in the Arkhangelsk province, the first producing non-economic evolved kimberlites of the Kepino cluster and the second producing economic-grade diamondiferous kimberlites.
\end{abstract}

Keywords: Arkhangelsk diamond province; kimberlite; kimberlitic sills; phlogopite; spinel; melt evolution

\section{Introduction}

Kimberlites are rare volatile-rich ultramafic alkaline rocks and are the primary source of diamonds. The petrology of kimberlites, their primary melt composition, and their magmatic evolution remain controversial because kimberlitic melts are highly reactive and interact with mantle and crustal wall rocks during their rise to the surface $[1,2]$.

Usually, kimberlite magmas have been explosively emplaced as pipes, which therefore are composed of volcanoclastic units that vary by their content of magmatic material, mantle and crustal xenoliths, and host-rock material. Less commonly, kimberlites form hypabyssal dykes and sills [1,3-9]. Kimberlite sills are known in the Kimberley area of South Africa; in Rhodesia; in the Singida and Kimali areas of Tanzania; in southwestern Greenland; in the Slave Province in the Northwest Territories, Canada; and in the Arkhangelsk diamond province (ADP) in Russia [3,8-12]. Kimberlite sills commonly reflect in situ magmatic differentiation to carbonate-rich residua $[3,5,6,8,12]$. 
Hypabyssal kimberlites as sills cannot be used to estimate compositions of the primitive kimberlite magmas as they have lost olivine phenocrysts and undergone crystal-liquid fractionation [12] but could be considered as representing evolved kimberlite magmas. Apart from macrocrysts, hypabyssal kimberlites consist of primary microphenocrystal olivine, minor phlogopite, and chromium spinel set in a very fine-grained groundmass composed of one or more of the following primary minerals (mainly $<0.2 \mathrm{~mm}$ ): monticellite, phlogopite-kinoshitalite (solid solution), perovskite, spinel, apatite, carbonate (calcite and/or dolomite), and serpentine [12]. Sills may vary in composition from macrocrystal kimberlites containing pyrope, ilmenite, and mantle xenoliths to highly evolved carbonaterich kimberlites (e.g., Benfontein, South Africa $[3,6]$ ) or to phlogopite-rich kimberlites (e.g., Wesselton Water Tunnels, South Africa [3,13]).

Hypabyssal kimberlites, especially sills, are helpful in studying the evolution of kimberlite magma, given that, when it is emplaced as pipes, normally it does not evolve. In hypabyssal kimberlites, groundmass minerals may exhibit zonation tracing melt evolution. Examples include early-crystallising Ti-Mg-Cr spinel that is compositionally zoned toward Ti-Mg-Fe spinel and phlogopite with late-stage overgrowths of orange tetraferriphlogopite [14]. In such cases, widely applied mineralogical-genetic classification of kimberlites and kimberlite-related rocks (i.e., orangeites, aillikites, etc.) based on the composition of phlogopite and spinel may not accurately identify the evolved kimberlites (such as archetypal kimberlites [15]) and correlate them with aillikite or orangeite magmas.

The timespan for the formation of a kimberlite pipe, kimberlite cluster, or kimberlite province remains unresolved. The duration of discrete episodes of kimberlite magmatism in the North American province [16-18] has been variously estimated as 1-3, 4-5, or $\leq 10$ m.y. Also, recent studies have shown that kimberlite pipe formation requires a prolonged period of time. U-Pb dating of perovskite in the groundmass of kimberlite from sequential intrusive bodies (dykes or sills) and explosive phases demonstrate that the duration of kimberlite pipe formation can take as long as 20 m.y. (e.g., [19,20]). Kimberlite and kimberlite-related rocks of the Yakutia province, Siberia Craton, Russia are good examples of multi impulses ultramafic alkaline magmatism within one craton. Yakutian kimberlite and kimberlite-related magmas formed during four episodes: (1) Late SilurianEarly Devonian, 419-397 Ma; (2) Late Devonian-Early Carboniferous, 376-347 Ma; (3) Late Triassic, 231-215 Ma; and (4) Middle/Late Jurassic, 171-156 Ma [21-28]. This means that a period of kimberlite province development may be much more extended than previously assumed, and new age data for various kimberlite bodies (pipes, sills, or dykes) are significant to help clarify the duration of kimberlite evolution.

Although ADP kimberlites have been studied and mined for $>40$ years, unresolved geological and petrological questions remain. In particular, significant questions remain regarding the province that includes the Kepino kimberlite cluster, which differs from other ADP kimberlites by many features: petrography, mineralogy, emplacement style, wall-rock geology, and diamond grade. This cluster contains bodies of carbonate-silicate and ultramafic alkaline rocks, which many researchers have classified as alkaline picrite or other kimberlite-related rocks instead of kimberlite (e.g., [29]). Many kimberlite bodies in the Kepino cluster are sills, whereas only pipes were observed in other ADP clusters. Compositional variation among sedimentary xenoliths and degree of laterite profile preservation indicate different geological situations when the Kepino rocks intruded compared to those when other ADP kimberlites formed.

In this study, we examined petrography and mineral composition of Kepino cluster kimberlite and, coupled with an analysis of previously published geochemistry data, determined the petrography, mineralogy, and geochemistry of highly evolved carbonate-rich kimberlites. This allowed their classification and clarified the link between emplacement style and the evolution of the kimberlite magma. $\mathrm{Rb}-\mathrm{Sr}$ dating of the Kepino kimberlite sill revealed a stage of kimberlite magmatism that was 20 m.y. earlier than the main ADP magmatic pulse and that temporally matched far-field stresses related to the Caledonian orogeny and ADP magmatic episodes. 


\section{Geological Background and Samples}

\subsection{Arkhangelsk Diamond Province}

The ADP is in the northeastern part of the East European Craton (Figure 1a). The ADP includes more than 90 pipes and sills of kimberlite and kimberlite-related ultramafic alkaline rocks, including alkaline picrites, olivine melilitites, and carbonatites [29-38]. The kimberlites and kimberlite-related rocks intruded into Neoproterozoic-Paleozoic sedimentary rocks and were overlain by Carboniferous siliciclastic and carbonate rocks and by Quaternary sediments. Based on chemical composition, the kimberlite and kimberliterelated rocks separate into $\mathrm{Fe}-\mathrm{Ti}$ series and $\mathrm{Mg}-\mathrm{Al}$ series $[29,33,38,39]$. The Fe-Ti series comprises the kimberlites of the Chernoozero (the Grib pipe) and the Kepino clusters, alkaline picrites of the Megorsk clusters and carbonate-bearing kimberlite sills of the Mela River. Their geochemical and isotopic characteristics are similar to the Group 1 kimberlites of South Africa and reflect their asthenospheric mantle source [39,40]. The Grib kimberlite is diamondiferous, but other kimberlites and kimberlite-related rocks of the $\mathrm{Fe}-\mathrm{Ti}$ series vary from being diamond barren to rocks with an extremely low grade of diamond ( $<0.1$ carats per ton). The $\mathrm{Mg}-\mathrm{Al}$ series includes kimberlites of the Zolotica and Verkhotina clusters and picrites and olivine melilitites of the Chidviya, Izhma, Nenoksa, and Suksoma clusters. Their geochemical and $\mathrm{Sr}-, \mathrm{Nd}-, \mathrm{Pb}$-isotopic compositions suggest contribution from an ancient lithospheric mantle source [39,40]. Kimberlites from the Zolotica cluster are diamondiferous and form the Lomonosov deposit. Geological setting, petrography, and geochemical characteristics of the ADP magmatism have been detailed in prior research [29,31-34,38,41,42]. Basalt pipes emplaced by explosive intrusion occur in the eastern part of the ADP [29,36] (Figure 1a).

The age of the diamondiferous kimberlites varies within the range $375 \pm 2 \mathrm{Ma}$, which overlaps the estimated age range for alkaline rocks of the Kola Alkaline Carbonatite Province (KACP) [34,43], including the $376.9 \pm 0.4$ Ma Ermakovskaya-7 pipe [34] represented by evolved macrocrystic massive kimberlite, consisting of serpentinized olivine (25-30\%) set in a magnetite-carbonate-serpentine-olivine-phlogopite-apatite groundmass [34]. These data indicate that the kimberlite was emplaced roughly simultaneously with the early evolutionary episode of the KACP. In this case, the formation of large alkaline provinces and closely spaced kimberlite occurrences may be considered as a manifestation of a single tectonothermal event $[34,44]$.

The age of the diamond-barren kimberlites and kimberlite-related rocks of ADP, including kimberlites of the Kepino cluster, is still debated [34]. Geological and faunistic data have revealed a wide age range from Early Devonian to early Carboniferous, 410-340 Ma [31,34].

\subsection{Kepino Cluster}

The Kepino cluster is in the central part of the ADP and includes 31 pipes and sills divided into four groups: Shocha, Pachuga, Kluchevaya, and Soyana (Figure 1b). Previously, the Kepino rocks were classified as kimberlites, porphyry kimberlites, Febearing kimberlites, alkaline picrite, clinopyroxene-free alkaline picrite, or olivine melilitite $[29,30,35-37,41,45]$. The Kepino cluster, the largest among the ADP clusters, covers an area of $\sim 1200 \mathrm{~km}^{2}$ and is comparable to the Devonian kimberlite clusters of the Yakutian diamondiferous province in Siberia, Russia [46].

The Kepino pipes have rounded, elongated-ellipsoid shapes and are $\leq 680 \mathrm{~m}$ along the long axis. About half the pipes could be considered large and the rest medium in size; in surface exposure, the area of pipes varies between 0.36-10.8 ha (averaging $5.7 \mathrm{ha}$ ).

Generally, most parts of the pipes were formed during a single eruptive cycle represented by volcanoclastic that filled the crater (tuffs, tuffites, and tuffstones) and a diatreme zone (volcanoclastic breccias). 

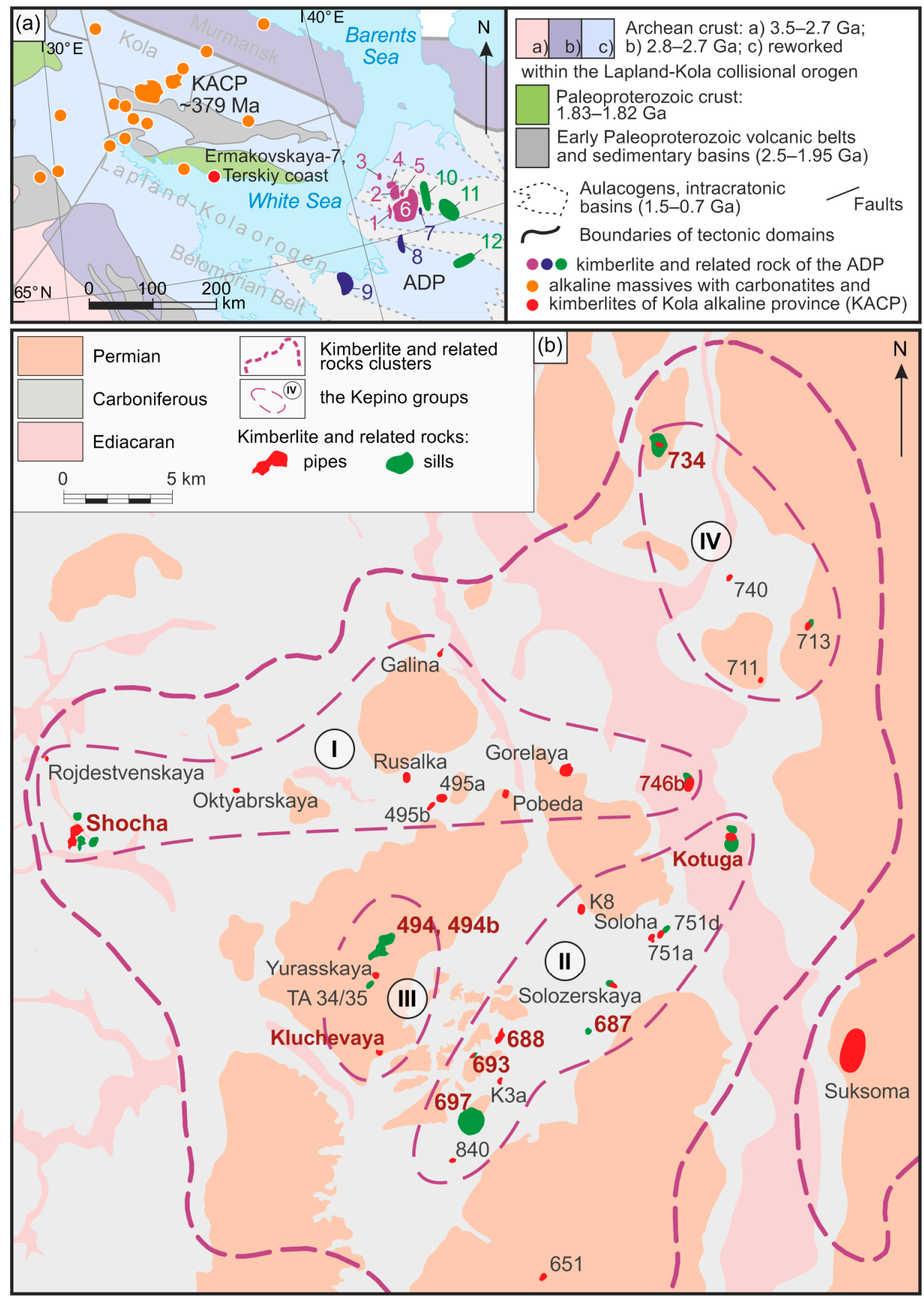

Figure 1. (a) Precambrian crust of the Fennoscandia (northeastern Archean part) after [47], showing areal extents of alkaline-ultramafic magmatism within the Kola alkaline carbonatite province (KACP) and the Arkhangelsk diamond province (ADP). The kimberlite and kimberlite-related rocks of the ADP: 1-6 are Zolotica (1), Chernoozero (the Grib pipe) (2), Mela River sills (3), Megorsk (4), Verhotina (5), and Kepino (6) clusters; 7-9 are picrites and olivine melilitites of the Suksoma (7), Chidviya-Izhma (8), and Nenoksa (9) clusters; 10-12 are basalts of the Soyana (10), Koval-Poltozero (11), and Chuplega-Pinejozero clusters (12). The ages of magmatism after [34,43]. (b) The schematic geological map of the Kepino kimberlite and kimberlite-related rocks cluster with the position of pipes and sills under overlying Permian and Carboniferous sedimentary rocks. The Kepino groups: I-Shocha-group; II-Pachuga-group; III-Kluchevaya-group; IV-Soyana-group. 
These units are characterised by high country-rock-fragment abundances (20-90 vol.\%). Crater-zone thickness varied within 1-130 m and was investigated within the 496, Shocha, and Galina pipes. Some pipes (e.g., pipes 693, 694, 734, and the Shocha pipe) have a multiphase composition and consist of volcanoclastic units or diatreme-filling massive macrocrystic kimberlite that varies in texture. One of the key differences between the Kepino kimberlite pipes and the diamondiferous kimberlite pipes of the Zolotica and Chernoozero clusters is the Kepino's lack of units with significant amounts of zoned pyroclasts, olivine macrocrysts or megacrysts, and mantle xenoliths.

The Kepino cluster is characterised by the widespread presence of sills of the kimberlite and kimberlite-related rocks (Figure 1b), which occur as spatially conjugated with pipes (sills 695, 713, 734, Shocha, Kotuga) or as discrete magmatic bodies (sills 494, 494b, 687, 697). Sills intrude on Ediacaran sedimentary rocks and are predominantly consistent with the subhorizontal bedding of the host rock [30-32]. Sills are composed of numerous layers, and some individual sills (e.g., sill 697) are as thick as $20 \mathrm{~m}$, but the average vertical extent of sills is $<1.0 \mathrm{~m}$. The area of the sills determined by geophysical methods [30,31] may be $\leq 100$ ha. The Kepino sills consist of coherent porphyritic kimberlites and are cut by younger pipes. In some occurrences, the associated pipes contain disintegrated fragments of the coherent sill units [32]. Locally, kimberlite sills are characterised by the presence of mature weathering crusts of laterite (composed of kaolinite and Fe hydroxides). The lateritic profiles constitute an exclusive characteristic of Kepino kimberlites among all the magmatic bodies of the ADP. Compared to the kimberlite, the lateritic profiles are characterised by higher $\mathrm{Fe}, \mathrm{Al}, \mathrm{Ti}$, and $\mathrm{P}$ and lower $\mathrm{Si}$ and $\mathrm{Mg}$. In some occurrences, the $\mathrm{Al}_{2} \mathrm{O}_{3}$ and $\mathrm{FeO}$ concentrations could be quite high (16.3 wt.\% and $42.8 \mathrm{wt} . \%$, respectively).

Based on the geological data, Golovin N.N. [32] suggest the sequence of the kimberlite units generation, which could be combined in a simplified geologic section (Figure 2):

1. the first stage is the intruding of coherent porphyritic kimberlites of sills;

2. the second stage is the generation of kimberlite pipes filled with volcanoclastic breccias; and

3. the late stage is the intruding of massive macrocrystic kimberlite as the second phase within kimberlite pipes.

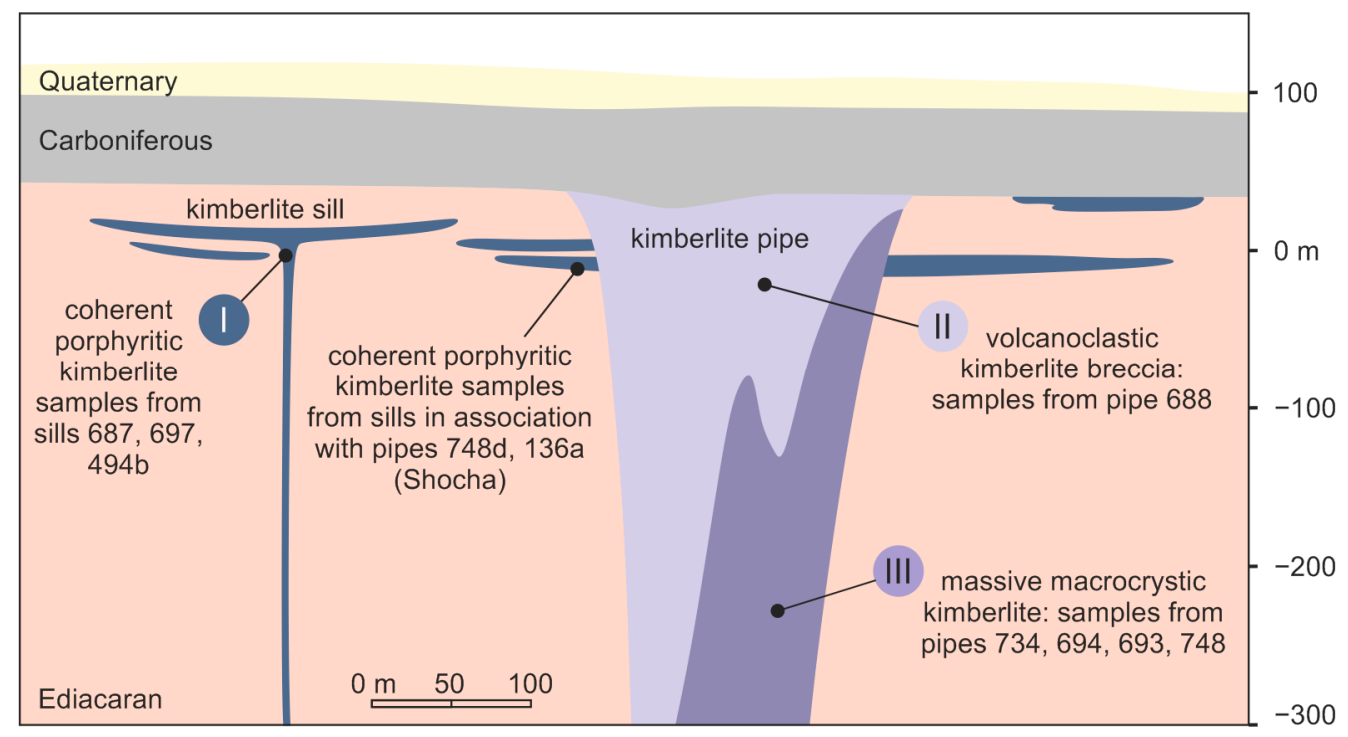

Figure 2. The simplified geological section of kimberlite magmatism of the Kepino cluster. The numbers are for kimberlite magmatism stages, according to Golovin N.N. [32].

The Kepino kimberlites and kimberlite-related rocks contain kimberlite indicator minerals such as garnet, ilmenite, Cr-bearing clinopyroxene, and $\mathrm{Cr}$ spinel. In most cases, abundant ilmenite is the dominant indicator mineral that distinguishes the Kepino kimberlites from diamondiferous kimberlites of the Zolotica cluster, which are ilmenite-poor 
kimberlites. Ilmenite and garnets from the Kepino kimberlites have been studied in detail $[42,48,49]$. The mantle-derived xenoliths within Kepino kimberlites are represented by garnet and spinel peridotite, ilmenite-bearing peridotite, dunite, and eclogite, of which the amounts and proportions vary through a wide range [38]. Unlike diamondiferous kimberlites from the Grib pipe, which contain mantle-derived xenoliths, the Kepino kimberlites lack mantle-derived clinopyroxenites, websterites, and phlogopite websterites xenoliths but are characterised by the presence of metasomatic amphibole-bearing mantle-derived xenoliths [50].

We have studied the petrography and composition of rock-forming minerals and analysed previously published geochemistry data for five sills and six pipes within the Kepino cluster (Table 1).

Table 1. The studied sills and pipes from the Kepino cluster.

\begin{tabular}{|c|c|c|c|c|c|}
\hline Group & Type & No. & Object & Sample & Kimberlite Type \\
\hline \multirow{2}{*}{ Shocha } & sill & $136 a$ & Shocha & $1219 \mathrm{~g}-79,1219 \mathrm{~b}-276$ & coherent porphyritic kimberlite; \\
\hline & pipe & $746 b$ & - & $746 b-1 / 216$ & $\begin{array}{l}\text { carbonate-bearing coherent } \\
\text { porphyritic kimberlite }\end{array}$ \\
\hline \multirow[t]{2}{*}{ Kluchevaya } & sill & $494 \mathrm{~b}$ & Zvezdochka & $494 b-715-1 / 2$ & $\begin{array}{c}\text { carbonate-bearing coherent } \\
\text { porphyritic kimberlite }\end{array}$ \\
\hline & pipe & 694 & Kluchevaya & AP24, 694-730-222 & massive macrocrystic kimberlite \\
\hline \multirow{6}{*}{ Pachuga } & pipe & 688 & - & AP15 & volcanoclastic kimberlite breccia \\
\hline & pipe & 693 & - & 693 & massive macrocrystic kimberlite \\
\hline & sill & 697 & - & $\begin{array}{c}\text { 697, AP65, AP66, } \\
\text { 697-4033-1154 }\end{array}$ & coherent porphyritic kimberlite \\
\hline & sill & 687 & - & AP64 & coherent porphyritic kimberlite \\
\hline & pipe & 748 & Kotuga & $748-3 / 131.6$ & $\begin{array}{l}\text { carbonate-bearing massive } \\
\text { macrocrystic kimberlite }\end{array}$ \\
\hline & sill & $748 d$ & Kotuga & $748 d-1 / 122.7$ & $\begin{array}{l}\text { carbonate-bearing coherent } \\
\text { porphyritic kimberlite }\end{array}$ \\
\hline Soyana & pipe & 734 & - & 734, 734-140, AP68 & massive macrocrystic kimberlite \\
\hline
\end{tabular}

\section{Materials and Methods}

Textural and mineral-zoning analyses were conducted using a JEOL scanning electron microscope (JSM-6480LV) at the Laboratory of Local Analytical Methods in the Geology Department at Moscow State University in Russia. Electron-probe studies were carried out on thin polished sections previously covered with a carbon layer. An Oxford Instruments X-MaxN energy dispersive spectrometer with an ultrathin window and a $50-\mathrm{mm}^{2}$ crystal's active zone area was used for analytical measurements. We used a 20-kV accelerating beam

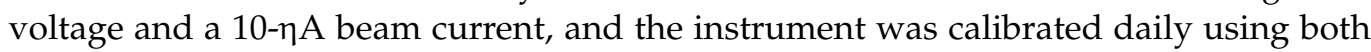
natural and synthetic standards.

The analysis of phlogopite was carried out on $10-\mathrm{mm}^{2}$ scanning areas, which minimised the migration of low-charged cations owing to the thermoelectric effect on the sample. The INCA shell (Oxford Instruments, v.21) was used to process the XPP correction algorithm's measurement results. Oxygen was calculated by stoichiometry. In the case of phlogopite, $\mathrm{Fe}$ and $\mathrm{Mn}$ were taken as bivalent during stoichiometry calculating. The systematic error of measurement (>10 wt.\%) of the main components, estimated according to the standards of the corresponding minerals, was $\leq 1$ rel.\%. For minor components (1-10 wt.\%), the relative error was within $\pm 5 \%$. The detection thresholds for all analysed elements did not exceed $0.03-0.05 \mathrm{wt} . \%$.

Concentrations of major elements of whole-rock samples were determined at the Institute of Geology of Ore Deposits, Petrography, Mineralogy and Geochemistry Russian 
Academy of Sciences (IGEM RAS) by X-ray fluorescence analysis using a Philips Analytical B.V. PW-2400 spectrometer. Samples were prepared by melting $0.3 \mathrm{~g}$ of powder with $3 \mathrm{~g}$ of lithium tetraborate in an induction furnace. The accuracy of the analysis was $1-5 \mathrm{rel} . \%$ for elements with concentrations of $>0.5 \mathrm{wt} . \%$ and $\leq 12$ rel. $\%$ for those $<0.5 \mathrm{wt} . \%$.

Minor and trace elements were determined by mass spectrometry with inductively coupled plasma mass spectrometry at the Institute of Microelectronics Technology and High Purity Materials Russian Academy of Sciences. The rock samples were decomposed using inorganic acids in a sealed autoclave. Sample decomposition during chemical disintegration was controlled by the addition of ${ }^{161} \mathrm{Dy}$. The detection limits (DL) were 0.02-0.03 $\mu \mathrm{g} / \mathrm{g}$ for rare-earth elements (REEs) and Hf, Ta, Th, and U; 0.03-0.05 $\mu \mathrm{g} / \mathrm{g}$ for $\mathrm{Nb}$, Be, and Co; $0.1 \mu \mathrm{g} / \mathrm{g}$ for $\mathrm{Li}, \mathrm{Ni}, \mathrm{Ga}$, and $\mathrm{Y} ; 0.2 \mu \mathrm{g} / \mathrm{g}$ for $\mathrm{Zr} ; 0.3 \mu \mathrm{g} / \mathrm{g}$ for Rb, Sr, and $\mathrm{Ba}$; and 1-2 $\mu \mathrm{g} / \mathrm{g}$ for $\mathrm{Cu}, \mathrm{Zn}, \mathrm{V}$, and $\mathrm{Cr}$. The correctness of analyses was controlled by measuring standard samples GSP-2, BM, SGD-1A, and ST-1. The content-determination error was $\leq 0.3 \%$ ( $\pm \sigma$ un.) for elements with $\mathrm{DL} \leq 5 \mu \mathrm{g} / \mathrm{g}$ and $\leq 0.15 \%$ ( $\pm \sigma$ up.) for those with DL $>5 \mu \mathrm{g} / \mathrm{g}$ [51].

Using standard chemical procedures for sample preparation, the $\mathrm{Rb}-\mathrm{Sr}$-isotopic compositions of three phlogopite fractions and one whole-rock fraction from the sill 697 sample were analysed by mass spectrometry, including thermal ionisation, in the Laboratory for Isotopic Geochemistry and Geochronology at the IGEM RAS. The Rb and $\mathrm{Sr}$ contents of the samples and ${ }^{87} \mathrm{Rb} /{ }^{86} \mathrm{Sr}$ were determined by isotopic dilution with a mixed ${ }^{85} \mathrm{Rb}-{ }^{84} \mathrm{Sr}$ tracer that was added to samples before chemical decomposition. Phlogopite fractions with $99 \%$ purity were selected, and portions weighing $~ 0.05 \mathrm{~g}$ were used in analysing bulk phlogopite samples. Chemical decomposition was carried out in sealed PFA-Teflon vessels in a 3:1 mixture of concentrated acids ( $\mathrm{HF}: \mathrm{HNO}_{3}$ ) at atmospheric pressure and a steady temperature of $160^{\circ} \mathrm{C}$ until samples attained complete dissolution. The procedure for their chemical preparation involved dissolving the sample in $6 \mathrm{M} \mathrm{HCl}$ at $120^{\circ} \mathrm{C}$. Cation-exchange chromatography was used to obtain pure $\mathrm{Rb}$ and $\mathrm{Sr}$ agents. The fractions were extracted in $2.4 \mathrm{M} \mathrm{HCl}$ using ion-exchange columns filled with $3 \mathrm{~mL}$ of BioRad W50 $\times 8$ cation exchanger with grains of 200-400 mesh size. Background contamination of the sample prepared by this procedure was $\leq 0.06 \mathrm{ng}$ for $\mathrm{Rb}$ and $\leq 0.01 \mathrm{ng}$ for $\mathrm{Sr}$. The $\mathrm{Rb}$ - and $\mathrm{Sr}-$ isotopic compositions of the extracted fractions were analysed with a Micromass 54 Sector multicollector thermal-ionisation mass spectrometer. The ${ }^{87} \mathrm{Sr} /{ }^{86} \mathrm{Sr}$ mass spectrometric measurements' correctness was controlled by systematic measurements of an international standard for Sr-isotopic composition, such as SRM-987. In the measured samples, the ${ }^{87} \mathrm{Sr} /{ }^{86} \mathrm{Sr}$ error was $\leq 0.003 \%$ ( $\pm 2 \sigma$ un) and the ${ }^{87} \mathrm{Rb} /{ }^{86} \mathrm{Sr}$ error was $0.5 \%$ ( $\pm 2 \sigma$ un.). Using common constant values in the calculations [52], $\mathrm{Rb}-\mathrm{Sr}$ ages of the samples were estimated by the method of isochronic construction. One mineral fraction of phlogopite was mixed with $3 \mathrm{~mL}$ of concentrated $\mathrm{HCl}$; the mixture $\left(\mathrm{phl}+\mathrm{HCl}\right.$ ) was digested at $100{ }^{\circ} \mathrm{C}$ for $24 \mathrm{~h}$ and again dried to obtain the final residue. The $\mathrm{Sr}$ concentrations decreased in samples mixed with $\mathrm{HCl}$, as indicated on reaction with carbonate that could form intergrowths with phlogopite. After mixing with $\mathrm{HCl}$, the ${ }^{87} \mathrm{Rb} /{ }^{86} \mathrm{Sr}$ value for phlogopite increased to 10.5 , a value that is close to one for phlogopite from the Zolotica cluster kimberlites $\left({ }^{87} \mathrm{Rb} /{ }^{86} \mathrm{Sr}\right.$ within 11.3-18.7 [34]).

\section{Results}

\subsection{Petrography}

We have studied the petrographic characteristic of kimberlites from both volcanoclastic kimberlite breccias and massive macrocrystic kimberlite units within pipes as well as coherent porphyritic kimberlites within sills (Table 1). In general, massive macrocrystic units from pipes' diatreme zones exhibit petrographic and other features similar to those of coherent porphyritic kimberlites: wide variations in the content of olivine and phlogopite macrocrysts and microcrysts as well as variations in groundmass composition (including the carbonates calcite and dolomite, serpentine, phlogopite, apatite, spinel, magnetite, and perovskite). The mineral assemblages were found to be typical of ultramafic alkaline 
rocks (such as kimberlites and orangeites) and of ultramafic lamprophyres (such as aillikite and aillikite-carbonatite) $[4,53,54]$. Olivine is complexly altered to serpentine, saponite, or carbonate. The kimberlite sill samples commonly are cut by late-stage veinlets filled with carbonate minerals.

\subsubsection{Kimberlite Pipes}

Volcanoclastic units filling the crater and upper parts of diatreme zones are represented by kimberlite breccias consisting of disintegrated fragments of large olivine macrocryst (size $>0.5 \mathrm{~mm}$ ) grains and olivine microcrysts ( $\leq 60 \mathrm{vol} . \%)$, rare macrocrysts and their fragments of phlogopite, ilmenite, garnet, and xenogenic fragments of host rocks or their minerals (carbonate, quartz, feldspars) set in carbonate-serpentine matrixes (Figure 3). Olivine grains vary in size within $0.1-5 \mathrm{~mm}$; large grains have angular, slightly rounded shapes and small grains are isometric and subidiomorphic in shape. Olivine grains are fully altered to serpentine and saponite (Figure $3 a, b)$. Phlogopite occurs as small $(<1 \mathrm{~mm}$ ), commonly deformed grains partly altered to chlorite (Figure $3 a, c)$. Ilmenite and garnet grains $[42,49]$ have angular to irregular shapes and are $\leq 5 \mathrm{~mm}$ in size (Figure $3 \mathrm{a}, \mathrm{d}$ ).
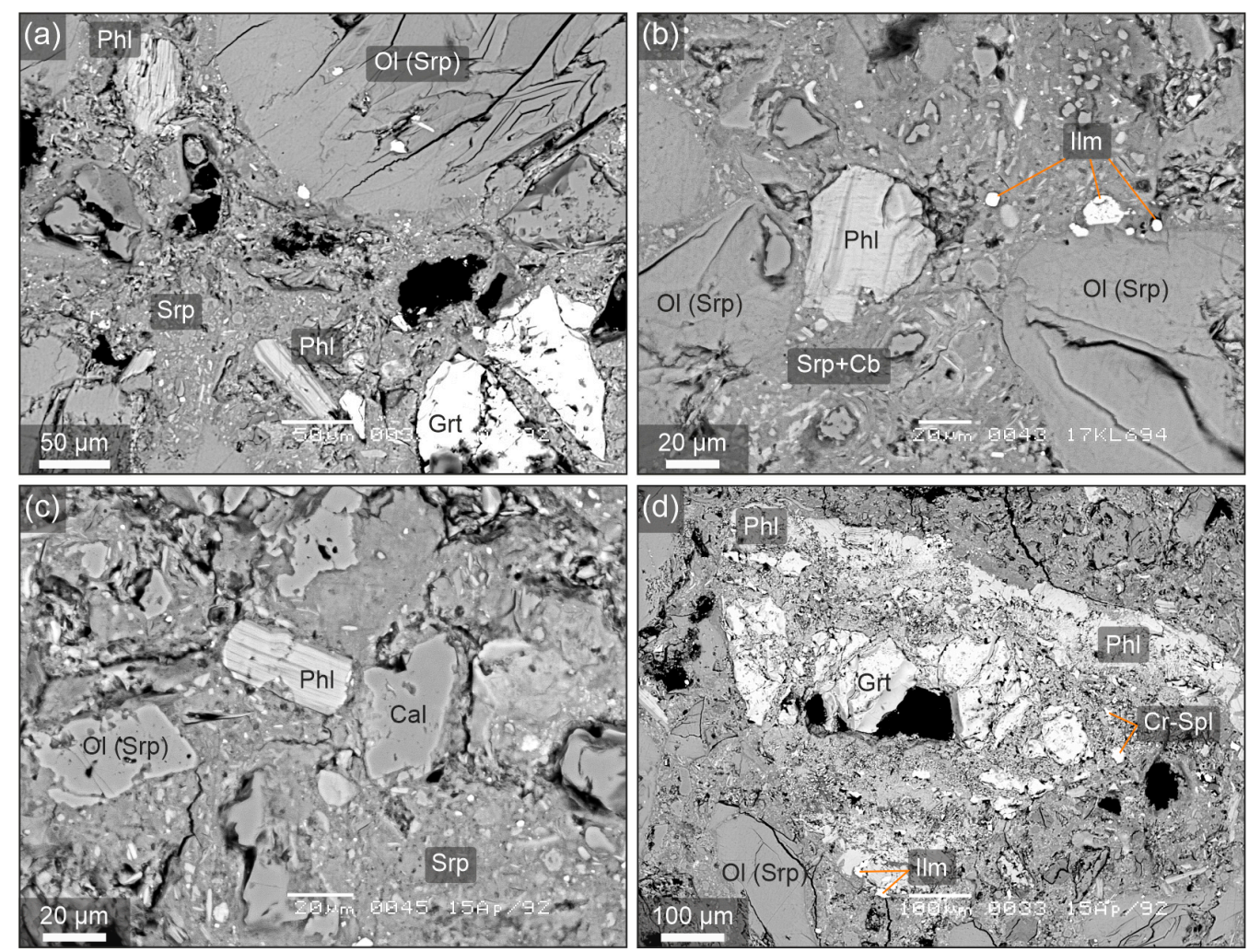

Figure 3. Back-scattered electron (BSE) images of volcanoclastic kimberlite breccias from pipe 688 (sample AP-92): (a) kimberlite matrix consists of serpentine, phlogopite, oxides with fragments of garnet xenocrysts and serpentinized olivine macrocrysts; $(\mathbf{b}, \mathbf{c})$ rare phlogopite grains set in the carbonate-phlogopite kimberlite matrix; (d) the fragment of garnet xenocryst partly altered to phlogopite. Cal—calcite; $\mathrm{Cb}$ - carbonate; $\mathrm{Cr}$-Spl-Cr-spinel; Grt-garnet; Ilm-ilmenite; Ol—olivine; $\mathrm{Phl}$-phlogopite; Srp—serpentine.

The massive macrocrystic kimberlites (previously called porphyritic kimberlites and autolithic kimberlites) consist of $\leq 60 \mathrm{vol} . \%$ juvenile magmaclasts $\leq 4 \mathrm{~mm}$ in size, set in a magmatic matrix (Figure 4). By magmaclasts we mean physically distinct, fluidal-shaped clasts of kimberlite magma (now solidified) interpreted to have formed by fluidal fragmentation or segregation processes prior to solidification, typically during near-surface emplacement events [55]. In the case of Kepino kimberlites, magmaclasts are melt segregations formed by segregationary processes in kimberlite magma. The magmaclasts 
studied from the Kepino pipe kimberlites are fully crystallised from magmas and have a porphyritic texture (Figure 4a). This is the main difference between the studied kimberlites and pyroclastic kimberlites from other ADP kimberlites (e.g., the Zolotica cluster and the Grib kimberlite), whereas magmaclasts commonly have xenogenic cores presented by fragments of large olivine grains of xenoliths of host rocks [34]. The Kepino magmaclasts have isometric or elongated rounded shapes and consist of subhedral or rare euhedral olivine grains $\leq 0.25 \mathrm{~mm}$ in size, set in a groundmass consisting of $\sim 60 \%$ phlogopite $(\leq 0.1 \mathrm{~mm})$ and $\sim 40 \%$ carbonate with minor apatite, $\mathrm{Cr}$ spinel, titanomagnetite, rare perovskite, rutile, and barite (Figure $4 \mathrm{~b})$. Some magmaclasts contain larger olivine grains $(\leq 3 \mathrm{~mm})$ with rounded anhedral shapes. Magmaclasts commonly contain carbonate segregations $(\leq 0.1 \mathrm{~mm})$ of elongated irregular shapes that are filled by calcite and dolomite (Figure $4 \mathrm{~d}$ ).

The matrix of massive macrocrystic kimberlites (Figure 4e,f) is magmatic and consists of the same minerals as in the magmaclast groundmass but differing from the latter by larger grain size and by higher carbonate contents and lower contents of oxide minerals. Phlogopite grains within both magmaclasts and matrix commonly are zoned and are rimmed by tetraferriphlogopite (Figure 4c). In some cases (e.g., Kotuga, 764b [56]), the late stage formed carbonate minerals that replace groundmass serpentine. In such samples, the boundaries between magmaclasts and matrix are not discernible. Some samples (pipes 693,734 ) are characterised by higher magmaclast content, causing the kimberlite sample to appear massive and thus comparable to coherent kimberlite units.

\subsubsection{Kimberlite Sills}

Most of the studied kimberlite samples from sills (sills 136a (Shocha), 687, and 697) have porphyritic (Figure 5a) to hypidiomorphic-granular (Figure 5b) textures. Both textures may be apparent within a single sample. Porphyritic textures are characterised by the presence of olivine macrocrysts (5-15 vol.\%) and phenocrysts (50-60 vol.\%) set in a kimberlite groundmass (25-45 vol.\%). The olivine macrocrysts are rounded to angular and vary in size between $2-15 \mathrm{~mm}$.

Olivine phenocrysts have isometric, euhedral, and subhedral shapes and are 0.1-1.0 mm in size. The olivine is fully altered to serpentine (Figure 5a), and in some occurrences, the olivine is rimmed by titanomagnetite and rutile. Some samples contain rare garnet and spinel macrocrysts, with fragments ranging between $0.6-1.5 \mathrm{~mm}$ in size. Spinel macrocrysts are normally mantled by titanomagnetite. The kimberlite groundmass has a granular texture and consists of fine-grained phlogopite, spinel, titanomagnetite, apatite, ilmenite, perovskite, and carbonate. Spinel grains are rimmed by titanomagnetite and perovskite is replaced by rutile. The size of groundmass grains generally is $<50 \mu \mathrm{m}$, but phlogopite may be 100-200 $\mu \mathrm{m}$ long. The proportion of phlogopite in the groundmass decreases with increasing olivine phenocrysts.

Kimberlite sill samples with hypidiomorphic-granular textures (sills 136a (Shocha) and 697) have mineral compositions similar to the porphyritic varies and are characterised by approximately equal grain sizes of olivine and phlogopite $(200-500 \mu \mathrm{m})$. Phlogopite $(\leq 500 \mu \mathrm{m})$ from these samples exhibit two different petrographic textures: discrete slightly elongated phenocrysts or their intergrowths or poikilitic grains with numerous inclusions of titanomagnetite and spinel as well as irregular serpentine inclusions.

In some occurrences, the sill samples characteristically have significant amounts of carbonate minerals ( $\leq 50 \mathrm{vol} . \%$ ) (e.g., sill $494 \mathrm{~b})$, which suggests that they are transitional between kimberlite and carbonatite. The variation in carbonate content of the kimberlite sills is characteristic of ADP kimberlite sills (e.g., the Mela River sills [8]) as well as sill kimberlites from some other regions (e.g., [3,6]). The carbonate-bearing massive macrocrystic kimberlites have holocrystalline and taxite textures and consist of granoblastic carbonate segregations ( $40 \mathrm{vol} . \%)$ set in a fine-grained matrix of carbonate, serpentine, phlogopite, oxides, and apatite (Figure $6 a, b$ ). 

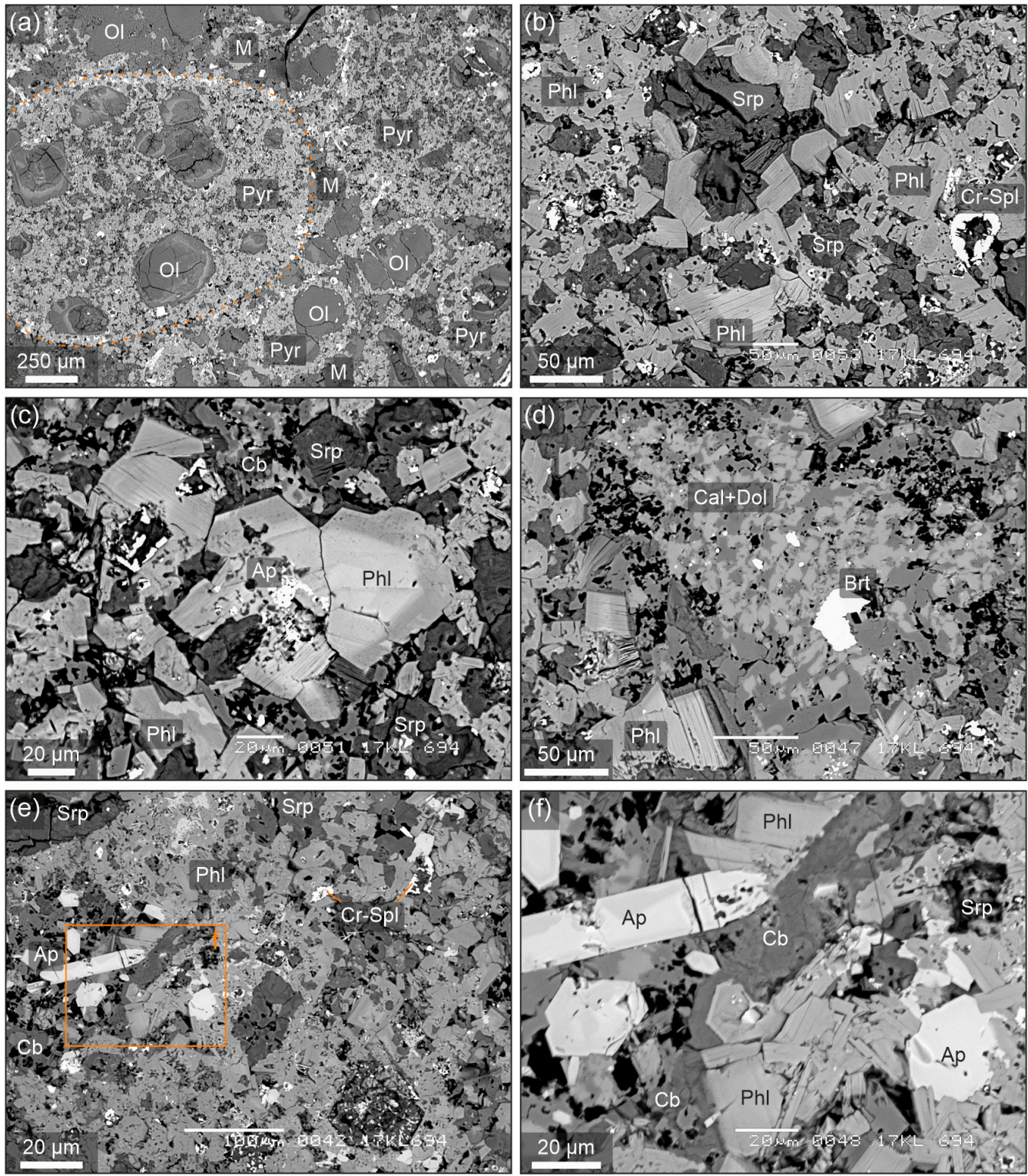

Figure 4. BSE images of massive macrocrystic kimberlite from pipe 694 (sample KLCh-694-730-222): (a) kimberlite magmaclasts set in the kimberlite matrix presented by magmatic kimberlites with micro-porphyry texture; (b) the magmaclast groundmass consists of small phlogopite grains, serpentine with minor spinel and apatite; (c) zoned phlogopite grains set in groundmass of magmaclast; (d) carbonate segregation consists of calcite and dolomite intergrowth; $(\mathbf{e}, \mathbf{f})$ the matrix of massive macrocrystic kimberlite. Ap—apatite; Brt-barite; Cal—calcite; $\mathrm{Cb}$-carbonate; $\mathrm{Cr}-\mathrm{Spl}$-chromium spinel, Dol—dolomite; M-matrix; Ol—serpentinised olivine; Phl—phlogopite; Pyr—pyroclasts; Srp-serpentine.

Carbonate segregations (calcite-dolomite intergrowths) have rounded lenticular and locally irregular shapes, are $0.5-4 \mathrm{~mm}$ across, and in some occurrences are mantled by spinel and titanomagnetite grains (Figure $6 \mathrm{a}, \mathrm{b}$ ).

The groundmass may contain $\leq 10$-vol. $\%$ zoned carbonate $(\leq 0.5 \mathrm{~mm})$ phenocrysts and commonly complexly zoned phlogopite $(\leq 1.0 \mathrm{~mm}$ ) phenocrysts (Figure $6 \mathrm{c}, \mathrm{d})$. The phenocrysts are set in a fine-grained matrix of phlogopite, apatite, titanomagnetite, carbonate, serpentine, rutile, and perovskite relicts mantled by rutile and titanomagnetite (Figure 6). 

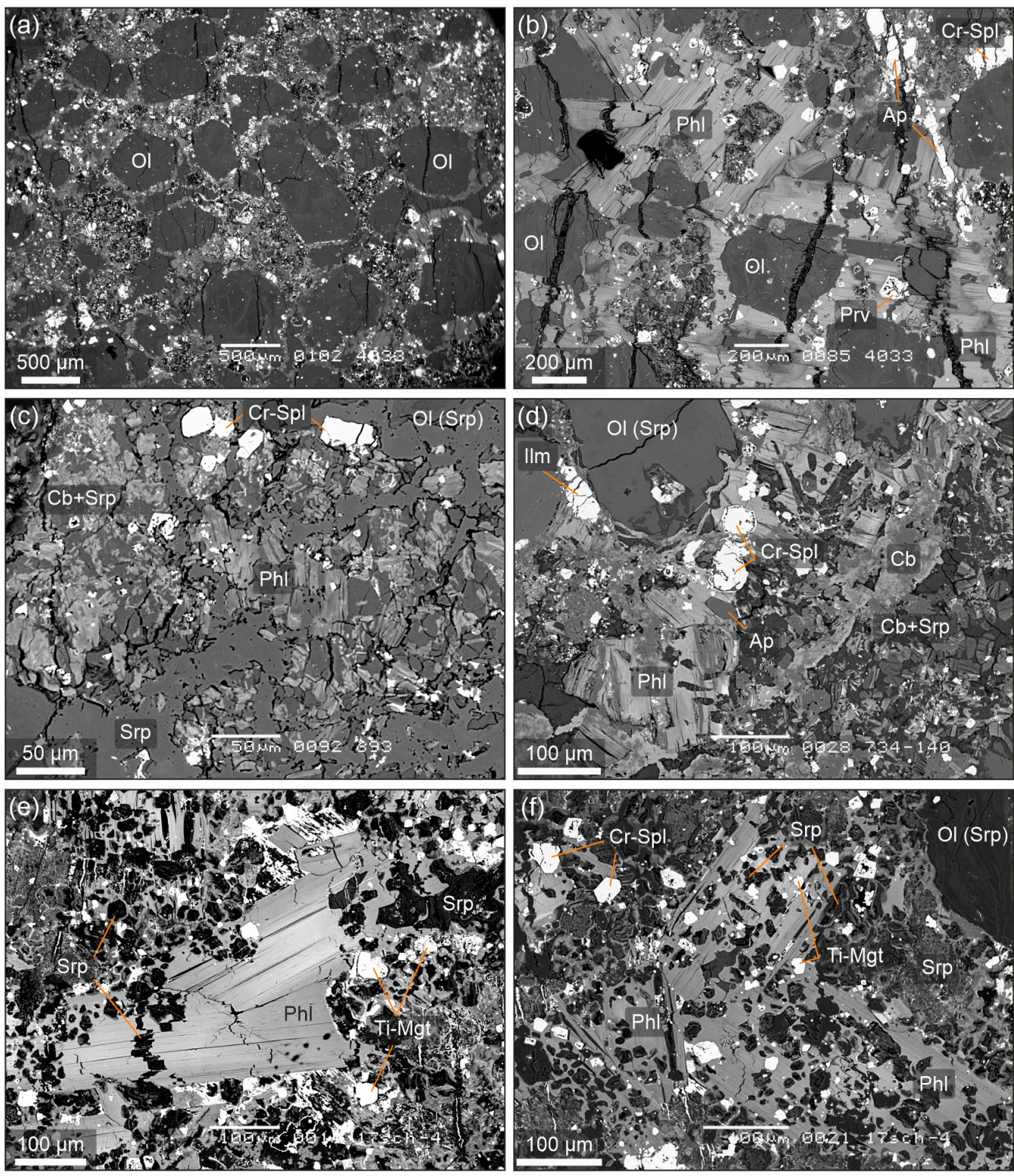

Figure 5. BSE images of coherent porphyritic kimberlite in the Kepino sills: (a) the porphyritic texture characterized by euhedral and subhedral olivine grains altered to serpentine and set in the magmatic groundmass consisted of phlogopite, serpentine, spinel rimed by magnetite, apatite, ilmenite, perovskite, rutile, and carbonate (sample 697-4033-1154); (b) the hypidiomorphic-granular texture presented by subhedral olivine grains, poikilitic phlogopite grains with inclusions of olivine, oxides, apatite, ilmenite, perovskite, and minor carbonate (sample 697-4033-1154); (c,d) two types of phlogopite grains (sample 1219b-276): (c) slightly elongated phenocryst grains or their intergrowths; (d) phlogopite grains with poikilitic inclusions of titanomagnetite, spinel and irregular inclusions filled by serpentine. (e) slightly elongated phlogopite phenocryst grains or their intergrowths; (f) phlogopite grains with poikilitic inclusions of titanomagnetite, spinel and irregular inclusions filled by serpentine. $\mathrm{Cb}$ - carbonate; $\mathrm{Cb}+\mathrm{Srp}$ - carbonate-serpentine; $\mathrm{Cr}-\mathrm{Spl}$-chromium spinel, Ilm-ilmenite; Ol—olivine; Phl—phlogopite; Prv—perovskite; Srp—serpentine; Ti-Mgt—titanomagnetite.

A typical phlogopite phenocryst in these sill kimberlites consists of a relict core zone with wavy resorbed boundaries, which may represent mantle-derived antecrysts from previous failed kimberlite magmatic pulses at depth (Figure 6c); a metasomatic transitional zone (with fine-grained inclusions of spinel) that indicates interaction of the core with kimberlitic magma (Figure 6c,d); and phlogopite with poikilitic inclusions of 
carbonate, spinel, magnetite, and serpentine that occur during the late stages of kimberlitic magma evolution.
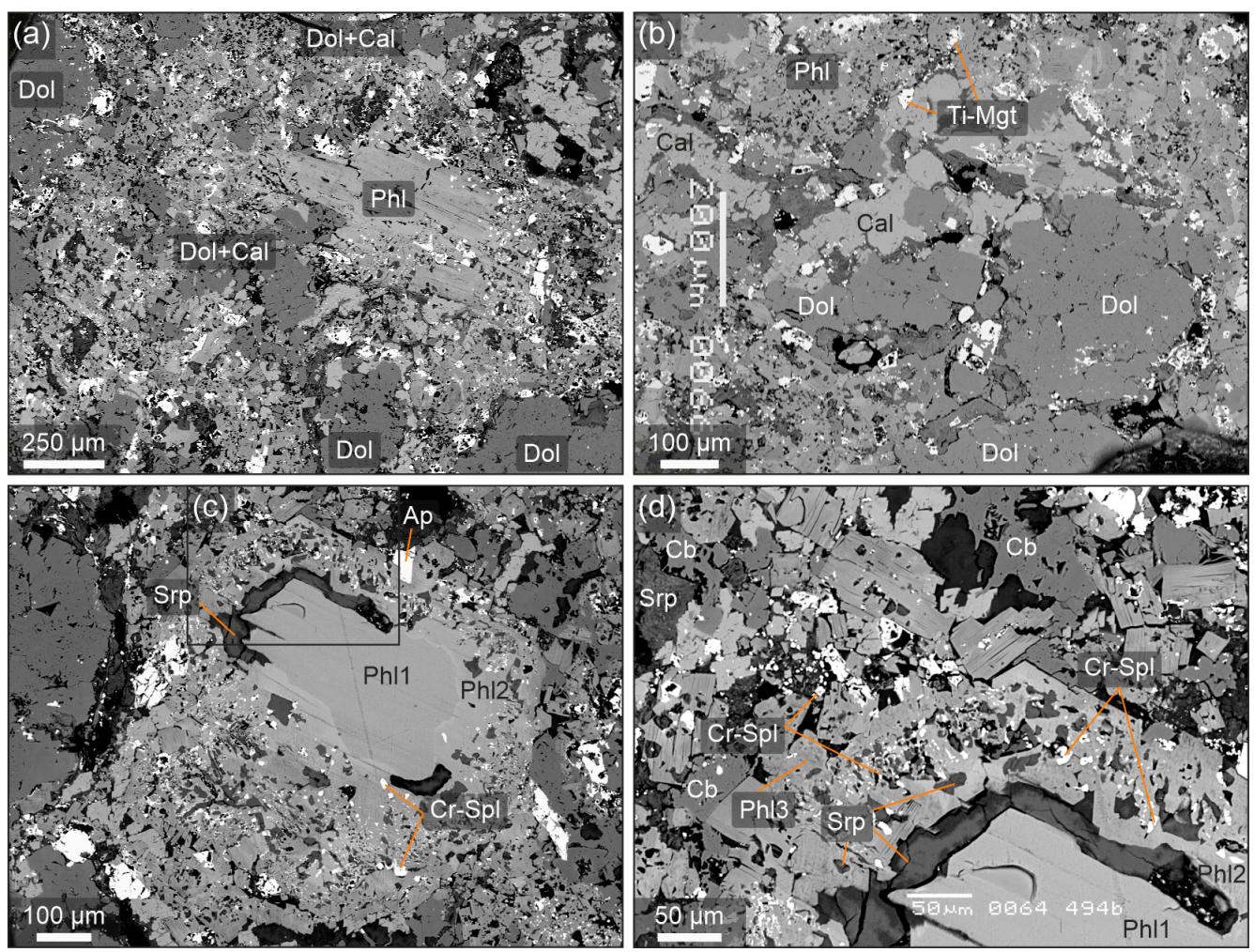

Figure 6. BSE images of carbonate-bearing coherent porphyritic kimberlite in the Kepino sills (sample 494b-715-1/2): (a) large phlogopite grains and carbonate segregations set in the fine-graded matrix of carbonate, serpentine, phlogopite, oxides, and apatite; (b) the carbonate segregations consist of calcite, and dolomite grains; (c,d) zoned phlogopite phenocryst consist of (i) a relict core zone with wavy resorbed boundaries (Phl1); (ii) a metasomatic transitional zone (with fine-grained inclusions of spinel) (Phl2) that indicates interaction of the core (Phl1) with kimberlitic magma; (iii) phlogopite (Phl3) with poikilitic inclusions of carbonate, spinel, magnetite, and serpentine (see panel d) that occur during the late stages of kimberlitic magma evolution. Ap-apatite; Cal—calcite; $\mathrm{Cb}$-carbonate; $\mathrm{Cr}-\mathrm{Spl}$ —chromium spinel; Dol—dolomite; Dol + Cal—dolomite and calcite intergrowths; Phl—phlogopite; Srp—serpentine; Ti-Mgt—titanomagnetite.

\subsection{Mineral Composition}

In most of the mineral assemblages, much of the olivine and some of the phlogopite show intense alteration: olivine is almost entirely replaced by serpentine, carbonate, and / or saponite; phlogopite is partly altered to chlorite. Also, chromium spinel is mantled by titanomagnetite and perovskite is replaced by rutile, ilmenite, and carbonate.

\subsubsection{Phlogopite}

Major-element results for phlogopite samples are presented in the Supplementary Materials, Table S1 and Figures S1-S10. We also compared the phlogopite compositions with data for phlogopite from other ADP kimberlites, including the diamondiferous kimberlite of the Grib pipe [57] and the Zolotica cluster (Supplementary Materials, Table S2); with phlogopites from evolved kimberlites of the Ermakovskaya-7 pipe ([58] and references therein) along the Tersky coast of the Kola Peninsula (Supplementary Materials, Table S2), from ultramafic lamprophyres (UML) of Aillik Bay in Canada [59], as well as orangeites and lamproites from the Kostomuksha area in Karelia, Russia [60].

The studied phlogopites from the Kepino cluster show a wide range of major-element concentrations: they form a single compositional trend from phlogopites with moderate 
$\mathrm{TiO}_{2}$ and low $\mathrm{FeO}$ concentrations to tetraferriphlogopite with low $\mathrm{Al}_{2} \mathrm{O}_{3}$ and high $\mathrm{FeO}$ concentrations (Figures 7 and 8).
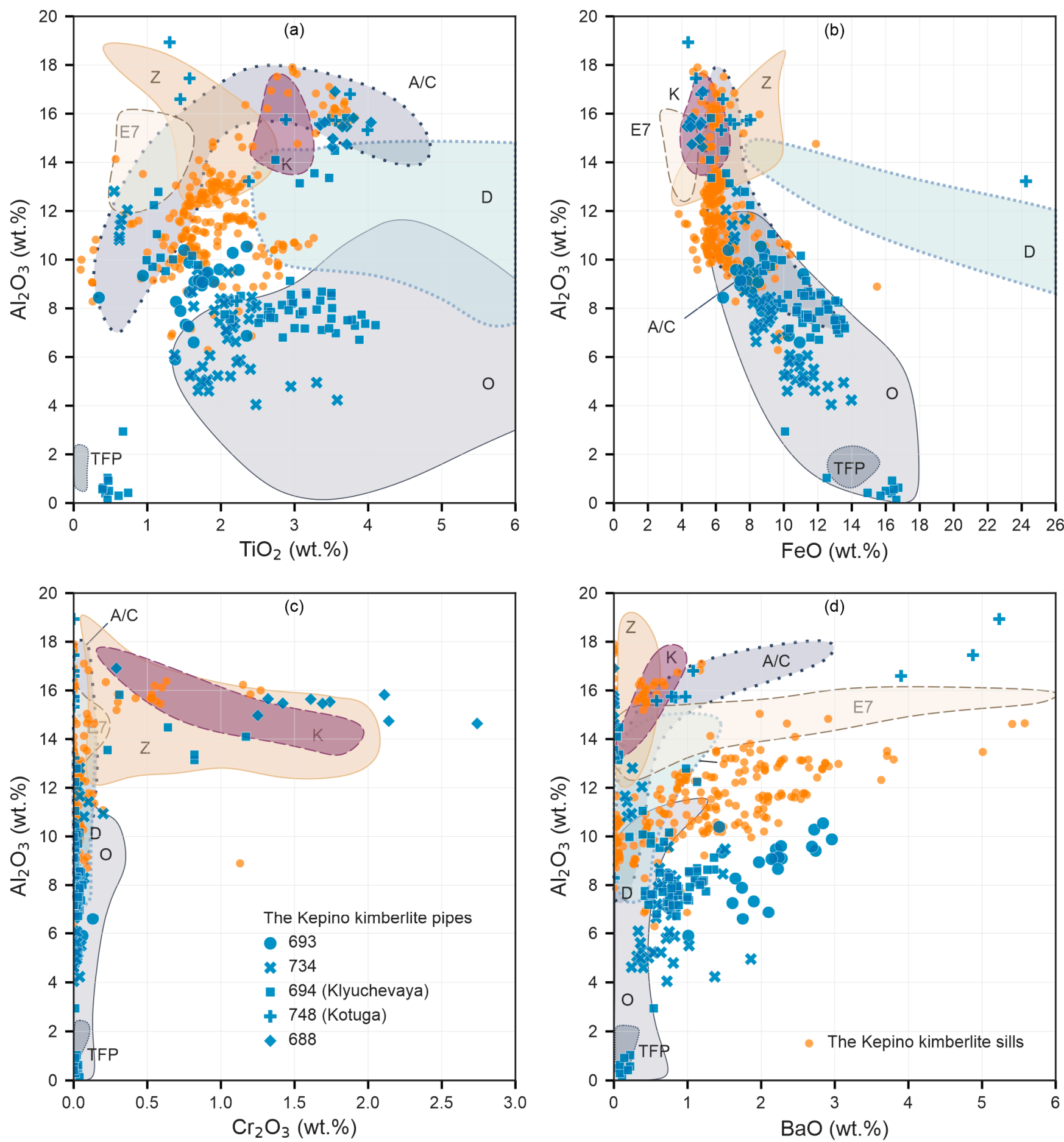

Figure 7. Bivariate plots $\mathrm{Al}_{2} \mathrm{O}_{3}$ vs. $\mathrm{FeO}(\mathbf{a}), \mathrm{Al}_{2} \mathrm{O}_{3}$ vs. $\mathrm{Cr}_{2} \mathrm{O}_{3}$ (b), $\mathrm{Al}_{2} \mathrm{O}_{3}$ vs. $\mathrm{TiO}_{2}$ (c), $\mathrm{Al}_{2} \mathrm{O}_{3}$ vs. $\mathrm{BaO}$ (d) for the phlogopite from the Kepino cluster kimberlites with detalisation for kimberlite pipes. The " $\mathrm{K}$ " field is for phlogopite phenocrysts and microphenocrysts from pyroclast groundmass and kimberlite matrix from the Grib kimberlite, ADP, based on [57]. The " $\mathrm{O}$ " field is for phlogopite from orangeites of Kostomuksha, Karelia, Russia, based on [60]. The "Z" field is for phenocrysts and microphenocrysts kimberlites of the Zolotica cluster, ADP (Supplementary Materials, Table S2). The "E7" field is for phlogopite from Ermakovskaya-7 pipe, Kola Peninsula (Supplementary Materials, Table S2). "A/C", "D" and “TFP" fields are for phlogopite from ultramafic lamprophyres and carbonatites from Aillik Bay, Canada, based on [59]: “A/C"—aillikites and carbonatites; “TFP"—-tetraferriphlogopite rims from aillikites; “ $\mathrm{D}$ ”-damtjernites and mela-aillikites. 

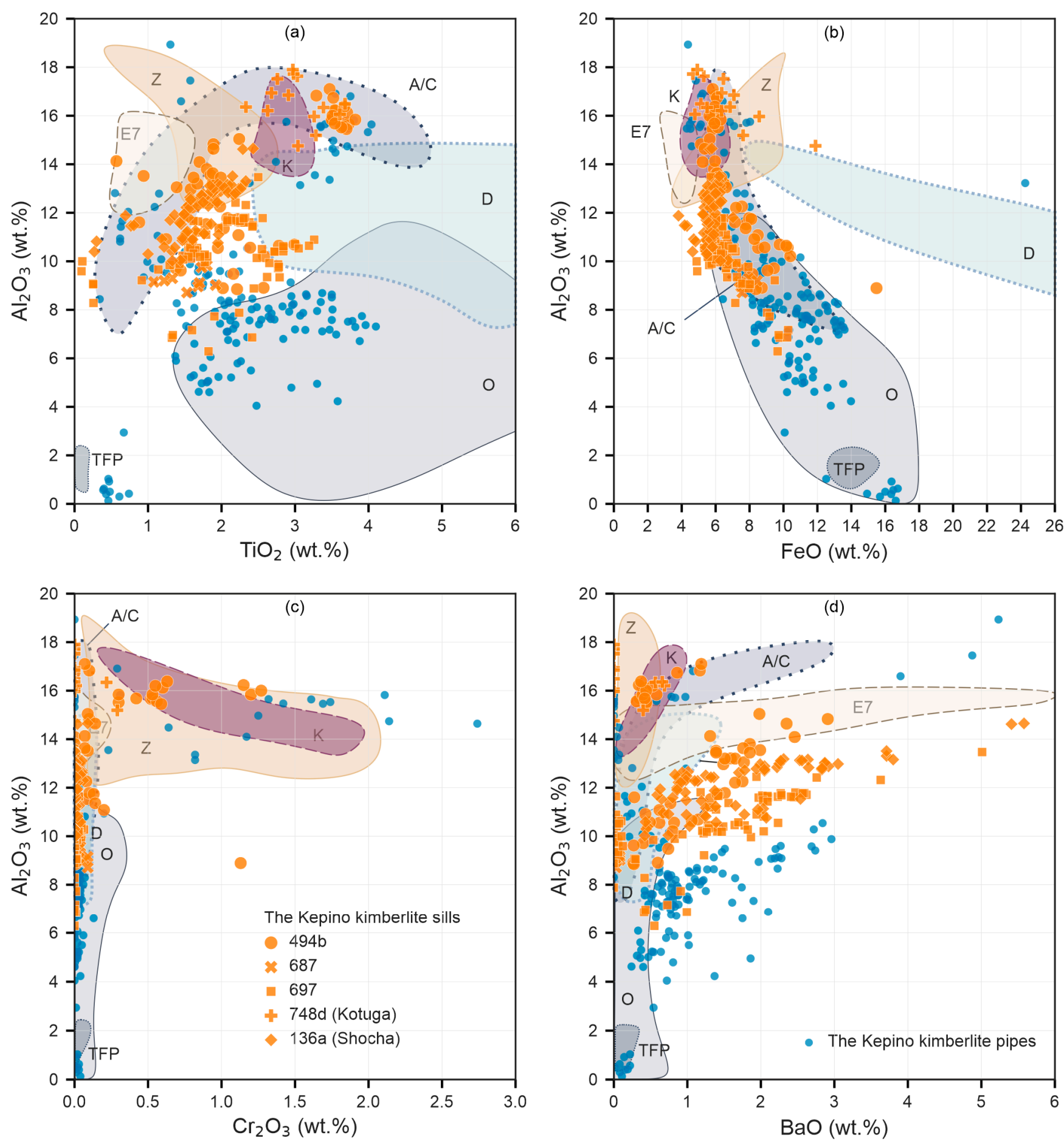

Figure 8. Bivariate plots $\mathrm{Al}_{2} \mathrm{O}_{3}$ vs. $\mathrm{FeO}(\mathbf{a}), \mathrm{Al}_{2} \mathrm{O}_{3}$ vs. $\mathrm{Cr}_{2} \mathrm{O}_{3}$ (b), $\mathrm{Al}_{2} \mathrm{O}_{3}$ vs. $\mathrm{TiO}_{2}$ (c), $\mathrm{Al}_{2} \mathrm{O}_{3}$ vs. $\mathrm{BaO}$ (d) for the phlogopite from the Kepino cluster kimberlites with detalisation for kimberlite sills. The " $\mathrm{K}$ " field is for phlogopite phenocrysts and microphenocrysts from pyroclast groundmass and kimberlite matrix from the Grib kimberlite, ADP, based on [57]. The "O" field is for phlogopite from orangeites of Kostomuksha, Karelia, Russia, based on [60]. The "Z" field is for phenocrysts and microphenocrysts kimberlites of the Zolotica cluster, ADP (Supplementary Materials, Table S2). The "E7" field is for phlogopite from Ermakovskaya-7 pipe, Kola Peninsula (Supplementary Materials, Table S2). "A/C", "D" and “TFP" fields are for phlogopite from ultramafic lamprophyres and carbonatites from Aillik Bay, Canada, based on [59]: "A/C"—aillikites and carbonatites; “TFP"—-tetraferriphlogopite rims from aillikites; “ $\mathrm{D}$ ”—damtjernites and mela-aillikites.

Phlogopites from kimberlites from 688 and Kotuga pipes and Kotuga sill, presented as large macrocrystic or phenocrystic phlogopite grains, have concentrations of $\mathrm{Al}_{2} \mathrm{O}_{3}$ between 
13.4-18.9 wt.\%, moderate $\mathrm{TiO}_{2}$ (1.7-4.0 wt.\%), low $\mathrm{FeO}$ (4.3-10.1 wt.\%), widely variable $\mathrm{Cr}_{2} \mathrm{O}_{3}$ concentrations $(\leq 2.0 \mathrm{wt} . \%)$, and $\mathrm{Mg} \#$ values in the range $0.80-0.91$ (Supplementary Materials, Figures S2, S4 and S10). The BaO concentrations are $\leq 1.6 \mathrm{wt} . \%$. The composition of these phlogopites coincides with that of phlogopite phenocrysts from the Grib kimberlite and partly overlaps the compositional field of phlogopite from the Zolotica kimberlite but differs from aillikite phlogopite by having higher $\mathrm{Cr}_{2} \mathrm{O}_{3}$ concentrations (Figure 8).

Phlogopites from pipe 693 and sills 374, 687, 697 and Shocha kimberlites (Supplementary Material, Figures S2, S5, S8 and S9) have lower $\mathrm{Al}_{2} \mathrm{O}_{3}$ (4.7-14.7 wt. \%), $\mathrm{TiO}_{2}(0.6-3.1$ wt.\%), $\mathrm{Cr}_{2} \mathrm{O}_{3}(\leq 0.05$ wt.\%), and higher $\mathrm{FeO}(3.81-11.94 \mathrm{wt} . \%)$ and $\mathrm{BaO}(\leq 4.3 \mathrm{wt} . \%)$ concentrations than phlogopite from 688 and from Kotuga pipes and sill kimberlites (Figures 7 and 8). The Mg\# values vary within a wide range, 0.78-0.93. These phlogopites show a compositional evolution toward tetraferriphlogopite (i.e., Al depletion and Fe enrichment) (Figures $7 \mathrm{~b}$ and $8 \mathrm{~b}$ ) and partly overlap in composition with phlogopite from aillikitecarbonatite [53,59] as well as orangeite (i.e., [4]). However, the studied phlogopites differ from orangeite phlogopites by lower $\mathrm{TiO}_{2}$ and higher $\mathrm{BaO}$ concentrations (Figures 7 and 8). Phlogopites with different petrographic expressions within the Shocha samples (large phenocrysts and poikilitic grains) do not differ in composition (Supplementary Material, Figure S6). High $\mathrm{BaO}$ concentrations in the studied phlogopites are not common for phlogopite from either the ADP diamondiferous kimberlite or the UML (Figures 7 and 8) but are typical of evolved kimberlites such as those from the Ermakovskaya-7 pipe.

The zoned phlogopites from carbonate-bearing coherent porphyritic kimberlite (sill 494b) show wide composition variation. The relict-phlogopite zone overlaps phlogopite from 688 and Kotuga pipes and sill kimberlites by composition. Like phlogopite from other sill kimberlites, the transitional and rim zones show a compositional trend toward tetraferriphlogopite (Supplementary Material, Figure S7).

The relict Al-bearing phlogopites also resemble those described within massive macrocrystic kimberlite from the 694 pipe (Supplementary Material, Figure S1). Among the samples that have relict phlogopite, phenocrystic phlogopite and phlogopites from kimberlite matrix show transitional composition from Al-bearing phlogopite to tetraferriphlogopite. However, these phlogopites show relatively higher $\mathrm{Al}_{2} \mathrm{O}_{3}$ contents than similar phlogopites from other studied samples (Figures 7 and 8).

\subsubsection{Spinel Group Minerals}

Spinel formed fine grains within the kimberlite matrix and magmaclast groundmass as well as poikilitic inclusions within phlogopite grains. Additionally, spinel occurs as macrocrysts within volcanoclastic units and could replace ilmenite grains during the late stages of kimberlite magma evolution [48]. Spinel is a well-studied mineral from kimberlites and kimberlite-related rocks of the ADP; Garanin et al. [61] summarized their detailed petrological-genetic spinel classification. Here we describe the chemical composition of the spinel grains within the kimberlite matrix and magmaclast groundmass as it relates to kimberlite composition and evolution and to classification of the studied samples. Majorelement compositions of spinel are presented in Supplementary Materials, Table S3, and shown in (Figures 9 and 10).

Spinel from the Kepino kimberlites shows a wide compositional range between $\mathrm{Cr}$ spinel (with chromite and titanium-magnesian-aluminous chromite [3]); a solid solution of magnesian ulvöspinel, ulvöspinel, and magnetite (MUM) [3]; and titanomagnetite (Figures 9 and 10). $\mathrm{Fe}^{2+}$ total $/\left(\mathrm{Fe}^{2+}{ }_{\text {total }}+\mathrm{Mg}\right.$ ) ratios span a wide range $(0.44-0.89)$ (Figure 10) with strong variations of $\mathrm{Cr}_{2} \mathrm{O}_{3}$ ( $\leq 53.9$ wt.\%), $\mathrm{TiO}_{2}(0.2-21.2 \mathrm{wt} . \%)$, and $\mathrm{Al}_{2} \mathrm{O}_{3}$ (0.6-16.1 wt.\%). On $\mathrm{Cr} /(\mathrm{Cr}+\mathrm{Al})$ vs $\mathrm{Fe}^{2+} /\left(\mathrm{Fe}^{2+}+\mathrm{Mg}\right)$ and $\mathrm{Fe}^{3+} /\left(\mathrm{Fe}^{3+}+\mathrm{Al}+\mathrm{Cr}\right)$ vs $\mathrm{Fe}^{2+} /\left(\mathrm{Fe}^{2+}+\mathrm{Mg}\right.$ ) plots (Figure 9), the dominant composition of the spinel grains follows magmatic trend 1 [62], indicating transitional spinel composition from chromite to MUM. This trend is typical of kimberlitic spinel and reflects increasing oxygen fugacity $\left(f \mathrm{O}_{2}\right)$ during crystallisation of spinel and the evolution of volatiles with high carbonate content [62]. 

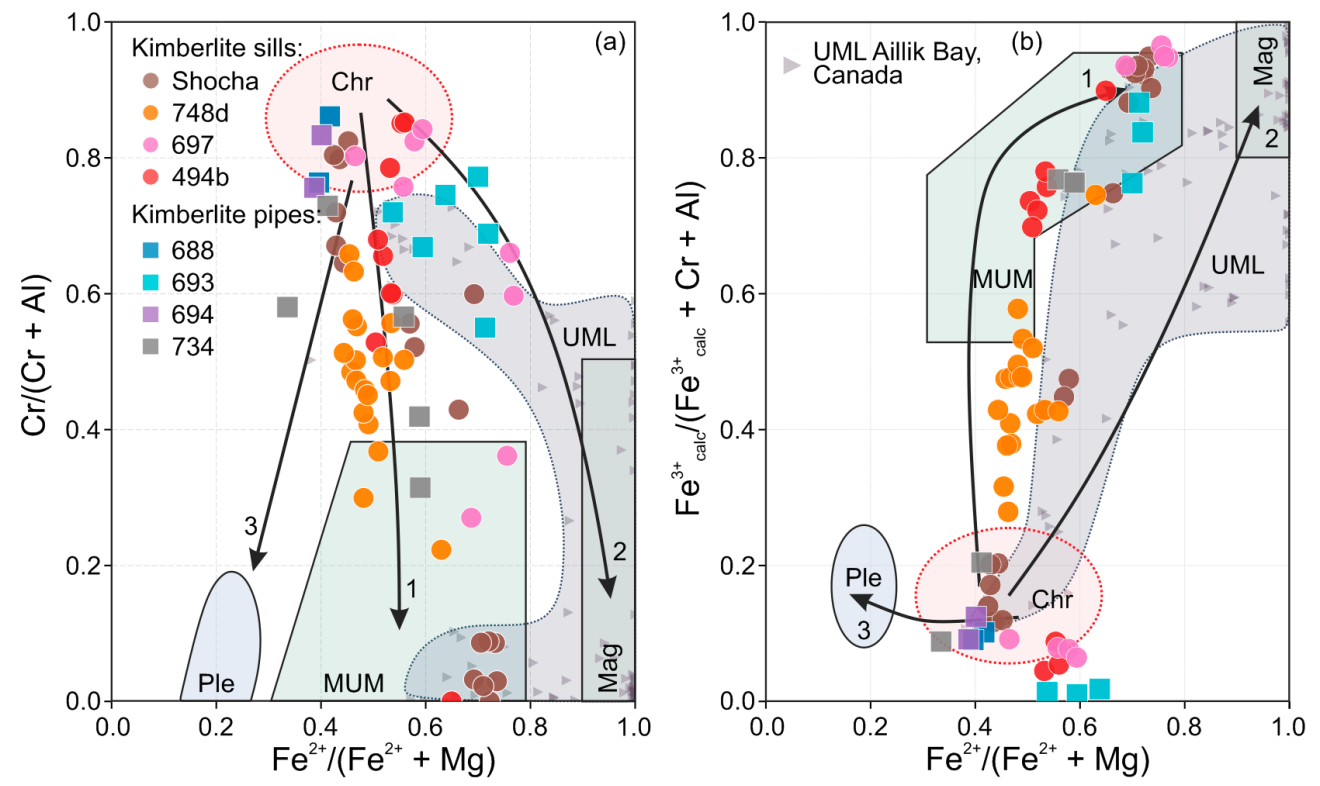

Figure 9. $\mathrm{Cr} /(\mathrm{Cr}+\mathrm{Al})$ vs. $\mathrm{Fe}^{2+} /\left(\mathrm{Fe}^{2+}+\mathrm{Mg}\right)(\mathbf{a})$ and $\mathrm{Fe}^{3+} /\left(\mathrm{Fe}^{3+}+\mathrm{Al}+\mathrm{Cr}\right)$ vs. $\mathrm{Fe}^{2+} /\left(\mathrm{Fe}^{2+}+\mathrm{Mg}\right)$ (b) variations of spinel grains from the Kepino kimberlites. Discrimination fields and magmatic evolution trends are from [62]: trend 1 indicates transitional spinel composition from chromite (Chr) to the solid solution of magnesian ulvöspinel, ulvöspinel, and magnetite (MUM); trend 2 indicates transitional spinel composition from chromite to magnetite (Mag); trend 3 indicates transitional spinel composition from chromite to pleonaste (Ple). Most of the spinel grains follow magmatic evolution trend 1 . The composition of the studied spinel partly overlaps the composition of spinel from UML Aillik Bay, Canada, based on [59].

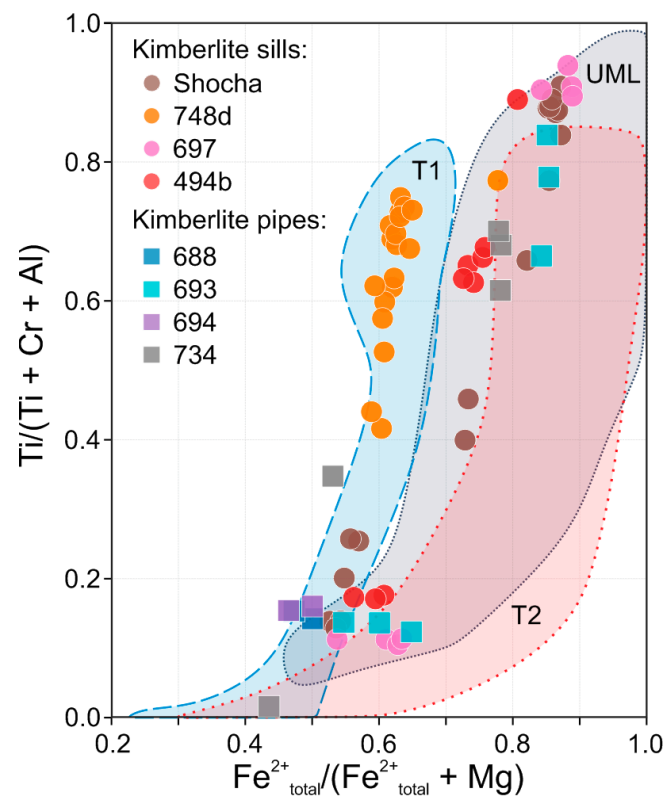

Figure 10. $\mathrm{Ti} /(\mathrm{Ti}+\mathrm{Cr}+\mathrm{Al})$ vs $\mathrm{Fe}^{2+}$ total $/\left(\mathrm{Fe}^{2+}\right.$ total $\left.+\mathrm{Mg}\right)$ variations of spinel grains from the Kepino kimberlites. Most of the studied spinel grains are transitional between the magnesian ulvöspinel (the $\mathrm{T} 1$ trend) and titanomagnetite (the T2 trend) trends and partly overlap composition of spinel from UML Aillik Bay, Canada, based on [59]. Trends T1 and T2 are based on [3,4].

Other zones within the spinel grains are closer to magmatic trend 2 than to magmatic trend 1 (Figure 9), which indicates co-crystallisation of spinel with Mg- and Al-rich silicate minerals (such as olivine and phlogopite) in the kimberlites [62]. On a $\mathrm{Ti} /(\mathrm{Ti}+\mathrm{Cr}+\mathrm{Al}$ ) vs. $\mathrm{Fe}^{2+}$ total $/\left(\mathrm{Fe}^{2+}\right.$ total $\left.+\mathrm{Mg}\right)$ plot (Figure 10$)$, the late-stage spinel grains that replaced ilmenite 
within kimberlites from sill 748d [48] correspond to the magnesian ulvöspinel trend 1 that is typical of kimberlitic spinel [4], whilst other spinels exhibit compositions transitional between the magnesian ulvöspinel trend and titanomagnetite trend 2, which is most typical of spinel from orangeites and lamproites [4]. In general, spinel from the Kepino kimberlites partly overlaps the composition of those from ultramafic alkaline lamprophyres [59].

\subsubsection{Ilmenite}

Ilmenite is a widespread mineral in the Kepino kimberlites but has not been found in all samples, although a group of ilmenite-bearing bodies has been identified. The group includes kimberlite pipes (748 Kotuga, 688, 751, 3Ka) and sills (734, 748d Kotuga, 693) (Figure 1). In these kimberlites, ilmenite content as higher as $4000-5000 \mathrm{~g} / \mathrm{ton}$. Within other kimberlite bodies, ilmenite is a rare mineral. In the Kepino kimberlites, ilmenite normally occurs as discrete microcrystic and macrocrystic $(0.4-4.0-\mathrm{mm})$ angular grains or in polymineralic clusters.

The ilmenite microcrysts and macrocrysts, which show typical compositions of the ilmenite from the kimberlites, are characterised by wide ranges of $\mathrm{MgO}(10-15 \mathrm{wt} . \%)$ and $\mathrm{Cr}_{2} \mathrm{O}_{3}(0.76-2.15$ wt.\%), low $\mathrm{MnO}(<0.45 \mathrm{wt} . \%)$, and a negative correlation of $\mathrm{FeO}$ and of $\mathrm{Fe}_{2} \mathrm{O}_{3}$ with $\mathrm{MgO}$ [42]. During interaction with kimberlite melts, both the $\mathrm{MgO}$ and $\mathrm{Cr}_{2} \mathrm{O}_{3}$ in ilmenite increase [48]. The trace-element composition varies across a wide range, with $\mathrm{Nb}, \mathrm{Ta}, \mathrm{Zr}, \mathrm{Zn}$, and $\mathrm{V}$ concentrations increasing with decreasing $\mathrm{MgO}$ and $\mathrm{Ni}$ [42].

These trends are typical of ilmenite from multiple kimberlite occurrences worldwide [63,64]. Kepino ilmenite shows high concentrations of $\mathrm{Nb}(\leq 2360 \mathrm{ppm})$ and its $\mathrm{Zr}(\leq 760 \mathrm{ppm})$ is higher than in ilmenites from diamondiferous kimberlites of the Grib pipe [42] and from kimberlite-related phlogopite-ilmenite-clinopyroxene mantle xenoliths and polymict breccias $[65,66]$. The high $\mathrm{Nb}$ and $\mathrm{Zr}$ also show a positive correlation with $\mathrm{MnO}(r=0.6-0.7 \mathrm{~s})$ (Supplementary Materials, Figure S11), which may reflect an increasing role of the carbonate component in parental melts [64]. Detailed major- and trace-element compositions of the studied Kepino ilmenite have been previously reported [42,48].

\subsection{Major- and Trace-Element Whole-Rock Chemical Composition}

We have studied the major- and trace-element compositions of the Kepino kimberlites based on prior-published data $[29,36,56]$ and on data obtained in this study (Figures 10 and 11). The composition of the Kepino kimberlites is presented in the Supplementary Materials, Table S4. The studied Kepino kimberlites have moderately high Mg\# values (0.82-0.87) with a wide variation in concentrations of $\mathrm{SiO}_{2}(29.3-36.4 \mathrm{wt} . \%), \mathrm{Al}_{2} \mathrm{O}_{3}(1.8-4.9 \mathrm{wt} . \%), \mathrm{TiO}_{2}$ (1.9-4.9 wt.\%), and $\mathrm{MgO}$ (24.9-34.1 wt.\%). The $\mathrm{TiO}_{2}$ concentrations are comparable to those for UMLs (Figure 11).

In general, the studied rocks are characterised by increasing $\mathrm{Al}_{2} \mathrm{O}_{3}, \mathrm{~K}_{2} \mathrm{O}$, and $\mathrm{P}_{2} \mathrm{O}_{5}$ with decreasing $\mathrm{Mg} \#$ values, whereas the concentrations of other major elements do not show any correlations with Mg\# values (Figure 11). In most cases, the $\mathrm{K}_{2} \mathrm{O}(0.21-1.76 \mathrm{wt} . \%)$ contents are higher than $\mathrm{Na}_{2} \mathrm{O}(0.10-0.53$ wt.\%). In comparison with other rocks of the $\mathrm{ADP}$, the studied rocks have higher $\mathrm{TiO}_{2}$ concentrations than the diamondiferous Zolotica cluster, the Grib kimberlite and the carbonate-bearing kimberlite of the Mela River sills, and evolved kimberlites of the Ermakovskaya-7 pipe (Figure 11b).

Based on $\mathrm{Al}_{2} \mathrm{O}_{3}, \mathrm{~K}_{2} \mathrm{O}$, and $\mathrm{P}_{2} \mathrm{O}_{5}$ concentrations, the studied rocks are intermediate between the Grib kimberlite and the evolved kimberlite from the Ermakovskaya-7 pipe (Figure 11) and have Mg\# values that are comparable with the kimberlites from the Ermakovskaya-7 pipe.

Comparing other groups of ultramafic alkaline rocks (such as aillikites and damtjernites), we found that our samples are most similar to the aillikites from Aillik Bay, Canada [59], which are characterised by high $\mathrm{Mg \#}$ values (Figure 11) but have higher $\mathrm{SiO}_{2}$, $\mathrm{Al}_{2} \mathrm{O}_{3}, \mathrm{~K}_{2} \mathrm{O}$, and lower $\mathrm{CaO}$ concentrations, which are affected by the more-abundant phlogopite in the Kepino rocks. Our studied rocks differ from orangeites by lower concentrations of $\mathrm{SiO}_{2}, \mathrm{Al}_{2} \mathrm{O}_{3}, \mathrm{~K} 2 \mathrm{O}$, and $\mathrm{CaO}$ and higher mean $\mathrm{Mg} \#$ values (Figure 11). 

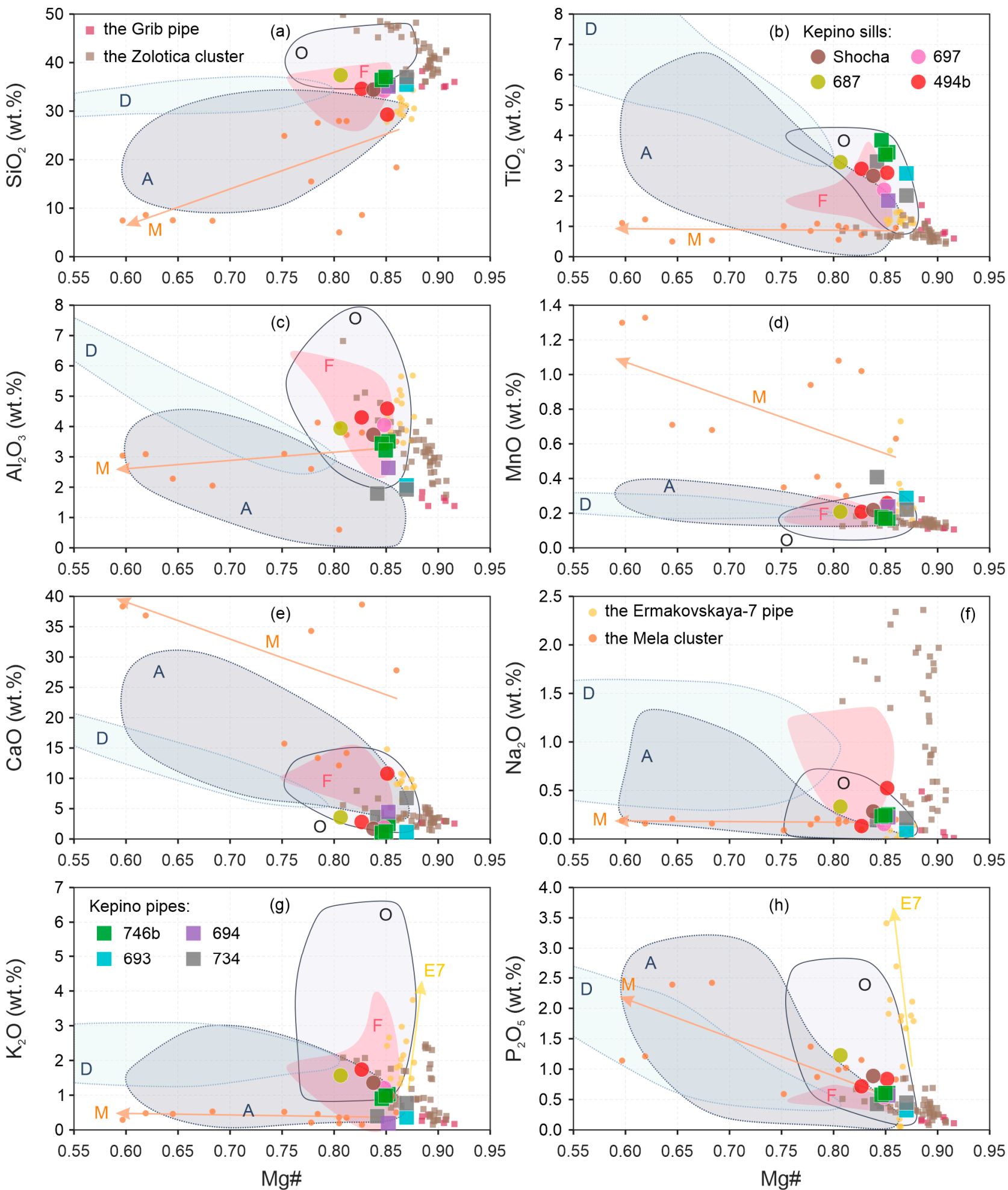

Figure 11. Binary diagrams $\mathrm{SiO}_{2}$ vs. $\mathrm{Mg} \#(\mathbf{a}), \mathrm{TiO}_{2}$ vs. $\mathrm{Mg \#} \mathrm{(b),} \mathrm{Al}_{2} \mathrm{O}_{3}$ vs. $\mathrm{Mg} \#($ c), $\mathrm{MnO}$ vs. $\mathrm{Mg \#} \mathrm{(d),} \mathrm{CaO}$ vs. $\mathrm{Mg \#} \mathrm{(e),}$ $\mathrm{Na}_{2} \mathrm{O}$ vs. $\mathrm{Mg \#}(\mathbf{f}), \mathrm{K}_{2} \mathrm{O}$ vs. $\mathrm{Mg \#}(\mathrm{g}), \mathrm{P}_{2} \mathrm{O}_{5}$ vs. $\mathrm{Mg \#} \mathrm{(h)} \mathrm{representing} \mathrm{the} \mathrm{major} \mathrm{element} \mathrm{composition} \mathrm{of} \mathrm{Kepino} \mathrm{cluster}$ kimberlites in comparison with other ultramafic-alkaline rocks of the ADP (the Grib kimberlite, Mela and Zolotica clusters, and the Ermakovskaya-7 pipe) as well as aillikites (the field " $\mathrm{A}$ ") and damtjernites (the field "D") from Aillik Bay, Canada [59], and orangeites form Kostomuksha (the field “ $\mathrm{O}$ "), Russia [60]. The field " $\mathrm{F}$ " is for kimberlites from Kaavi-Kuopio, Finland, based on [67]. The line " $\mathrm{M}$ " shows the compositional trend of carbonate-bearing kimberlite of the Mela River sills. The line "E7" shows the compositional trend of ultramafic alkaline rocks of the Ermakovskaya-7 pipe. 
The studied Kepino kimberlites are characterised by enrichment of incompatible elements, including light rare-earth elements (REE), strong fractionation of REEs ((La/Yb) $n$ : $60-140$ ), a positive anomaly of $\mathrm{Nb}-\mathrm{Ta}$, and a negative anomaly of $\mathrm{Sr}$ (Figure 12), which is typical of ultramafic alkaline rocks. Based on REE and high-field-strength elements content, two groups could be derived from the studied rocks (Figure 12a). The first group consists of kimberlite samples from pipes $693,734,746 \mathrm{~b}$, and is characterised by a positive anomaly of Ti relative to Eu-Gd and a slightly positive anomaly of $\mathrm{Zr}-\mathrm{Hf}$ relative to $\mathrm{Sm}$.
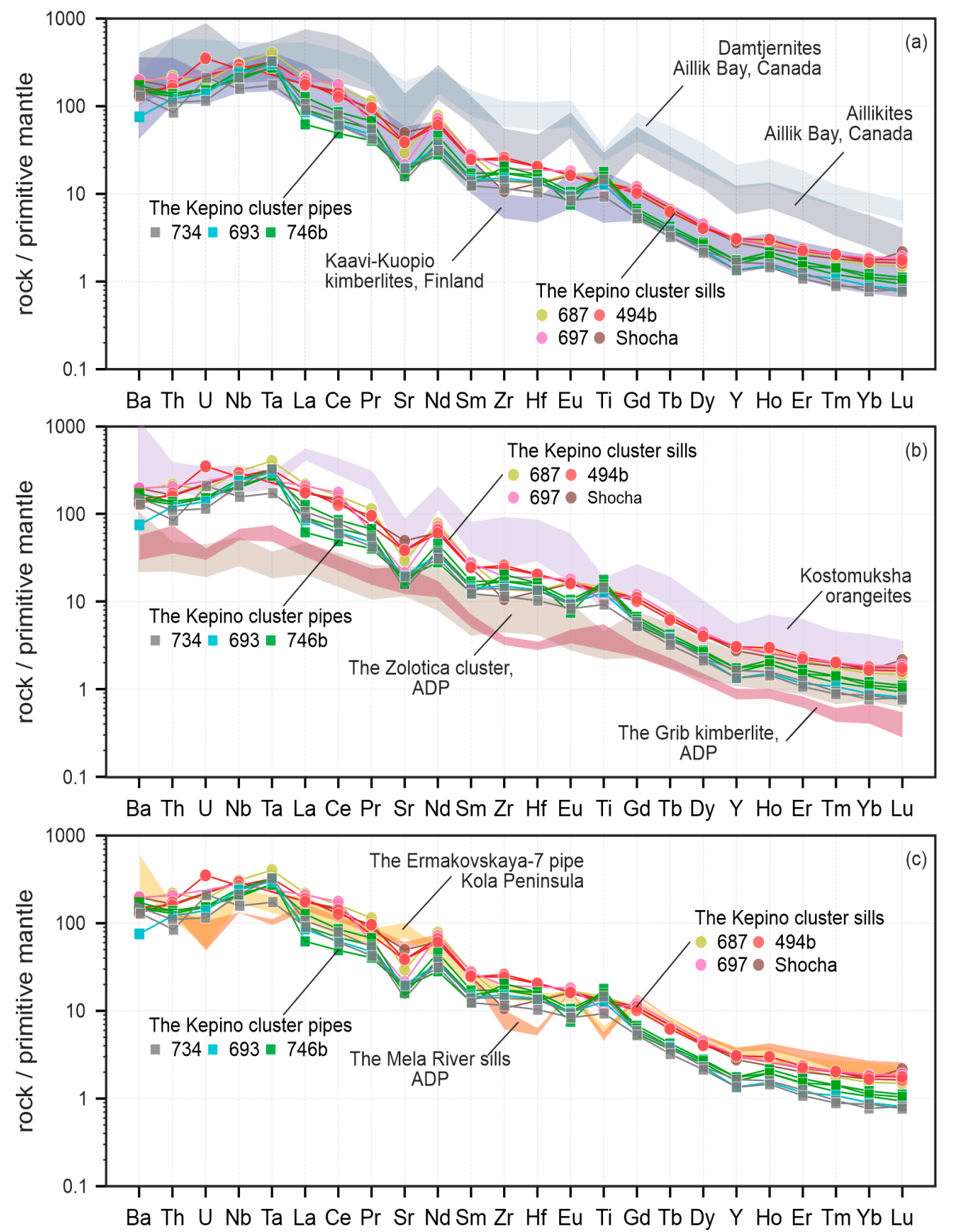

Figure 12. Trace elements normalised to primitive mantle [68] for kimberlites from the Kepino sills and pipes: (a) in comparison with aillikites and damtjernites from Aillik Bay, Canada, based on [59] and kimberlites from Kaavi-Kuopio, Finland, based on [67]; (b) in comparison with diamondiferous kimberlites of the Grib pipe and Zolotica cluster, ADP, and with orangeites of Kostomuksha area, Karelia, Russia [60]; (c) in comparison with carbonate-bearing kimberlite of the Mela River sills, ADP, and evolved kimberlites from the Ermakovskaya-7 pipe, Tersky coast, Kola Peninsula, Russia. 
The second group consists of kimberlite samples from sills 494b, 687, 697, and Shocha and is characterised by enrichment in all REEs relative to kimberlites from pipes and slightly negative anomalies of Ti and $\mathrm{Zr}-\mathrm{Hf}$ relative to REE or a lack of them. A comparison of studied kimberlites of the Kepino cluster with ultramafic alkaline lamprophyres [59] shows that the studied rocks have a lower amount of trace elements and differ by strong negative anomalies of $\mathrm{Zr}-\mathrm{Hf}$ and Ti related to REE (Figure 11a).

From diamondiferous kimberlites of the Grib pipe and Zolotica cluster, the studied kimberlites differ by a higher level of REE concentrations, a negative Sr anomaly, and a wider variation of $\mathrm{Zr}-\mathrm{Hf}$ and Ti concentrations (Figure 11b). By the level of REE enrichment and the fractionation style, the studied rocks, especially the Kepino sill kimberlites, are closer to the evolved kimberlites of the Kaavi-Kuopio area in Finland [67] (Figure 11a) and the evolved Ermakovskaya-7 kimberlites than to the carbonate-bearing kimberlite of the Mela River sills (Figure 11c).

\section{4. $R b-S r$ Isochron Age}

We determined $\mathrm{Rb}-\mathrm{Sr}$-isotopic compositions for three phlogopite fractions and one whole-rock fraction from the sill 697 sample (Table 2). The detailed petrographic characteristic of this sample is provided in Supplementary Material Figure S12. The Rb-Srisotopic compositions of three phlogopite and whole-rock fractions define an isochron age of $397.3 \pm 1.2 \mathrm{Ma}$ (MWSD, 4.0), with an initial ${ }^{87} \mathrm{Sr} /{ }^{86} \mathrm{Sr}$ ratio of $0.703763 \pm 0.000063$ (Figure 13). The obtained data confirmed the assumptions based on the geological data [69] about the relatively ancient age of the Kepino kimberlites compared to the diamondiferous kimberlites of the ADP [34].

Table 2. $\mathrm{Rb}-\mathrm{Sr}$ isotopic data on phlogopite from the kimberlite of the sill 697.

\begin{tabular}{cccccccc}
\hline Fraction & $\mathbf{R b}, \mathbf{p p m}$ & $\mathbf{S r}, \mathbf{p p m}$ & ${ }^{\mathbf{8 7}} \mathbf{R b} /{ }^{\mathbf{8 6}} \mathbf{S r}$ & ${ }^{87} \mathbf{S r} /{ }^{\mathbf{8 6}} \mathbf{S r}$ & $\pm \mathbf{2 \delta}{ }^{*}$ & $\mathbf{A g e}_{\mathbf{r}} \mathbf{M a}$ & ${ }^{\mathbf{8 7}} \mathbf{S r} /{ }^{\mathbf{8 6}} \mathbf{S r}(\mathbf{t})$ \\
\hline wallrock & 85.0 & 456 & 0.539 & 0.706828 & 0.000014 & 397 & 0.703779 \\
phl + HCl & 135 & 37.2 & 10.528 & 0.763325 & 0.000016 & 397 & 0.703769 \\
phl & 148 & 425 & 1.007 & 0.710497 & 0.000022 & 397 & 0.703735 \\
phl & 131 & 319 & 1.188 & 0.710497 & 0.000014 & 397 & 0.703777 \\
\hline
\end{tabular}

*28-two standard deviation values.

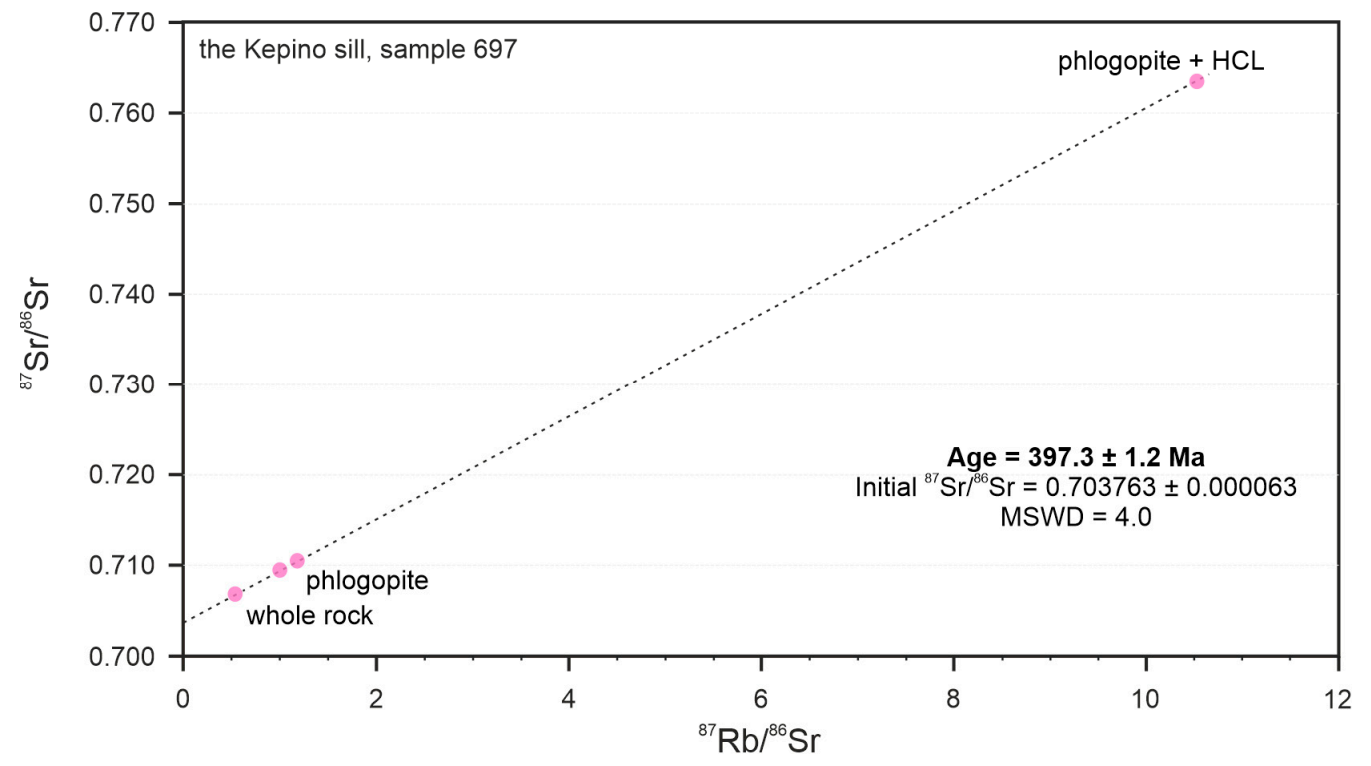

Figure 13. Rb-Sr isochron diagram for phlogopite and whole-rock fractions from sill 697. 


\section{Discussion}

\subsection{Nomenclature and Classification}

Based on reviewing studies of petrography and geochemistry of the ADP ultramafic alkaline rocks, some issues regarding the nomenclature and classification of the Kepino pipe and sill kimberlites remain. Previously, the Kepino rocks were classified as kimberlites, porphyry kimberlites, Fe-bearing kimberlites, alkaline picrite, clinopyroxene-free alkaline picrite, olivine melilitite, etc. $[29,30,35-37,45]$. The studied rocks contain an abundant amount of groundmass phlogopite and carbonate and a high proportion of macrocrystic and phenocrystic olivine, allowing us to consider the Kepino rocks as kimberlites, micaceous kimberlites, or ultramafic lamprophyres such as aillikite [53].

Compositions of both macrocrystic and groundmass minerals such as phlogopite and spinel from ultramafic alkaline rocks are commonly used for rock classification. This approach has been developed in detail by R.H. Mitchell for kimberlite, lamproite, and orangeite [3,4] and adapted for ultramafic lamprophyres [53].

Despite the versatility and long-term use of this approach, several investigated kimberlites from various worldwide occurrences, significantly evolved kimberlites, and late-stage subvolcanic units show that this approach should be applied only in conjunction with geochemical and petrographic studies [15].

Both the Kepino pipe and sill kimberlites are characterised by the wide compositional variation of phlogopite (Figure 7). Phlogopites that are mostly from pipe volcanoclastic units and relicts of phlogopite within some sill kimberlites show high $\mathrm{Al}_{2} \mathrm{O}_{3}$ and moderately high $\mathrm{FeO}$ and $\mathrm{TiO}_{2}$ concentrations that are similar to phenocrystic phlogopite from archetypal (Group 1) kimberlites of the ADP (Figure 7). Also, high $\mathrm{Cr}_{2} \mathrm{O}_{3}$ and moderate $\mathrm{BaO}$ concentrations separate them from phlogopites of ultramafic lamprophyres. Others phlogopites show a compositional evolution toward tetraferriphlogopite (Al depletion and Fe enrichment) (Figures 7 and 8). This trend locally occurs in ultramafic lamprophyres such as aillikites and associated carbonatites [53,59]; micaceous kimberlites or orangeites (i.e., [4]); rocks transitional between lamproites and orangeites from the Kostomuksha area in Karelia, Russia [60]; evolved kimberlites from the Mayeng and Wesselton kimberlite sills in South Africa [13,70] and in Kaavi-Kuopio, Finland [67]; and late-stage kimberlite dykes within the Premier diatreme root in South Africa [15].

The main differences between the studied phlogopites evaluated as trending toward tetraferriphlogopite and the ones from aillikite are the moderate concentrations of $\mathrm{TiO}_{2}$, which is more typical of phlogopite from orangeites than from aillikites $[4,53,59,60]$ and of phlogopite from evolved kimberlites of the Mayeng and Wesselton kimberlite sills in South Africa [13,70] and Kaavi-Kuopio, Finland [67]. The studied phlogopites are also characterised by having evolved $\mathrm{BaO}$ contents (Figure $7 \mathrm{~d}$ ), which is more common in phlogopite from evolved kimberlites [4,67], including the Ermakovskaya-7 pipe.

The groundmass spinel compositions are transitional from chromite to MUM (trend 1) and titanomagnetite (trend 2) (Figure 10). This trend is typical of spinel from ultramafic lamprophyres [59] rather than archetypal (Group 1) kimberlite [4,53] but is described for several kimberlite occurrences ([15,71] and references therein). However, late-stage spinel (formed during the interaction of ilmenite with host magmas [48] within the 748d sill) shows magmatic chromite on the MUM trend (trend 1) and therefore could be considered to be spinel crystallised from kimberlite melts.

Thus, phlogopite and spinel compositions show characteristics of archetypal kimberlites trending toward aillikitic or orangeitic compositions. This allows us to consider the studied rocks as transitional between kimberlite and aillikite or orangeite. This is consistent with the whole-rock chemistry (Figures 11 and 12): The studied samples show

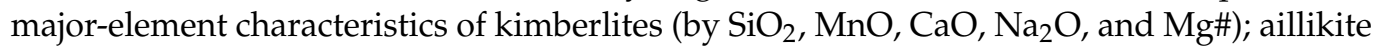
and orangeites (by high $\mathrm{TiO}_{2}$ ); evolved kimberlite of the Ermakovskaya-7 pipe, Kola Peninsula (by moderate high $\mathrm{P}_{2} \mathrm{O}_{5}, \mathrm{Al}_{2} \mathrm{O}_{3}$, and $\mathrm{K}_{2} \mathrm{O}$ concentrations); and overlap compositions of evolved kimberlites from Kaavi-Kuopio, Finland [67]. However, in spite of the compositional similarity between the studied phlogopites and phlogopites from orangeites, the lack 
of clinopyroxene within the Kepino rocks precludes their classification as orangeites [53]. Additionally, both pipe and sill kimberlites from the Kepino cluster contain ilmenite and garnet xenocrysts that are close in composition to low-chromium megacrysts $[42,48,49]$ and are more typical of Group 1 kimberlites than other kimberlite-related rocks.

In summary, although the studied phlogopite and spinel from the Kepino cluster samples differ from typical kimberlitic to aillikitic or orangeitic compositions, other petrographic and geochemical and isotopic-geochemical features indicate they belong to Group 1 kimberlites rather than kimberlite-related rocks. The compositional variety of phlogopite and spinel could be explained by the evolution of the kimberlitic melts (see Sections 5.2 and 5.3).

\subsection{Carbonate-Rich Melt in Kepino Sills and Pipes}

Petrography and chemistry of the Kepino kimberlites show that the sill kimberlites are significantly more carbonate-rich than kimberlites from the pipes. High carbonate content is typical of kimberlite sills worldwide (e.g., [7,72,73]), including the Mela River sills in ADP [8]. Carbonate enrichment in sills commonly presents as not only abundant calcite laths and microliths in the groundmass but also in the form of isolated bodiescarbonatite layers, lenses, segregations, bubbles, or ocelli. These textures are best explained by kimberlite melt fractionation and separation of residual evolved carbonate-rich melt by filter pressing or other processes that operated during sill emplacement (e.g., [72,73]).

Based on petrographic evidence that carbonates composing the segregations in the Kepino sills are likely primary phases, we suggest that differentiation of kimberlite melt has led to evolved carbonate-rich melt that exsolved or partly exsolved and coalesced into the segregations.

In contrast to the carbonate-rich sills, kimberlites of the Kepino pipes have low carbonate content and are relatively depleted in REEs and large-ion lithophile elements (LILEs) (Figure 12a). We suggest that the presence in sills of an evolved melt enriched in carbonate, REEs, and LILEs and the partial loss of the carbonate component in pipes causes the difference in chemistry between the sills and pipes. This can be verified by calculating major- and trace-element compositions of carbonatite melt equilibrated with the kimberlite of Kepino pipes, and by comparison of the modeled melt geochemistry with observed kimberlite of sills and pipes in the ADP. We computed the theoretical conjugate carbonatite compositions for the melt of the Kepino pipes based on experimental distribution coefficients for major and trace elements in natural hydrous $\mathrm{CO}_{2}$-bearing potassic compositions [74] (Supplementary Materials, Table S5). The resulting computed immiscible carbonatites compared with carbonatites in the Mela River sills are relatively Mg-rich and Ca-poor but have similar alkaline and $\mathrm{SiO}_{2}$ contents. The modeled trace-element patterns are very similar to the Mela River carbonatite (Figure 14a). This similarity suggests that the pipe kimberlite could have produced a carbonate component analogous to the carbonate component in the sill kimberlites.

Despite the fact that mass balance calculations provide no explanation for the mechanism of element fractionation, mixing models are successfully used to demonstrate the trend of the fractionation process (e.g., [75]). Our mass balance calculations using trace element concentrations (Supplementary Materials, Table S5) suggest that the mixture of $50 \%$ kimberlite of the Kepino pipes and 50\% modeled carbonatite melt shows a good match with the sill kimberlite (Figure 14b). This empirical result does imply that a difference in geochemistry between the pipe and sill kimberlites can be attributed mainly to the carbonatite component. It shows that the kimberlite melt evolution was exhibited towards carbonate-rich composition. Increasing carbonate content in sill kimberlites and massive macrocrystic kimberlite varieties is consistent with the presence of carbonate segregations, which are significant in samples from sill 494b (Figure 6b). 

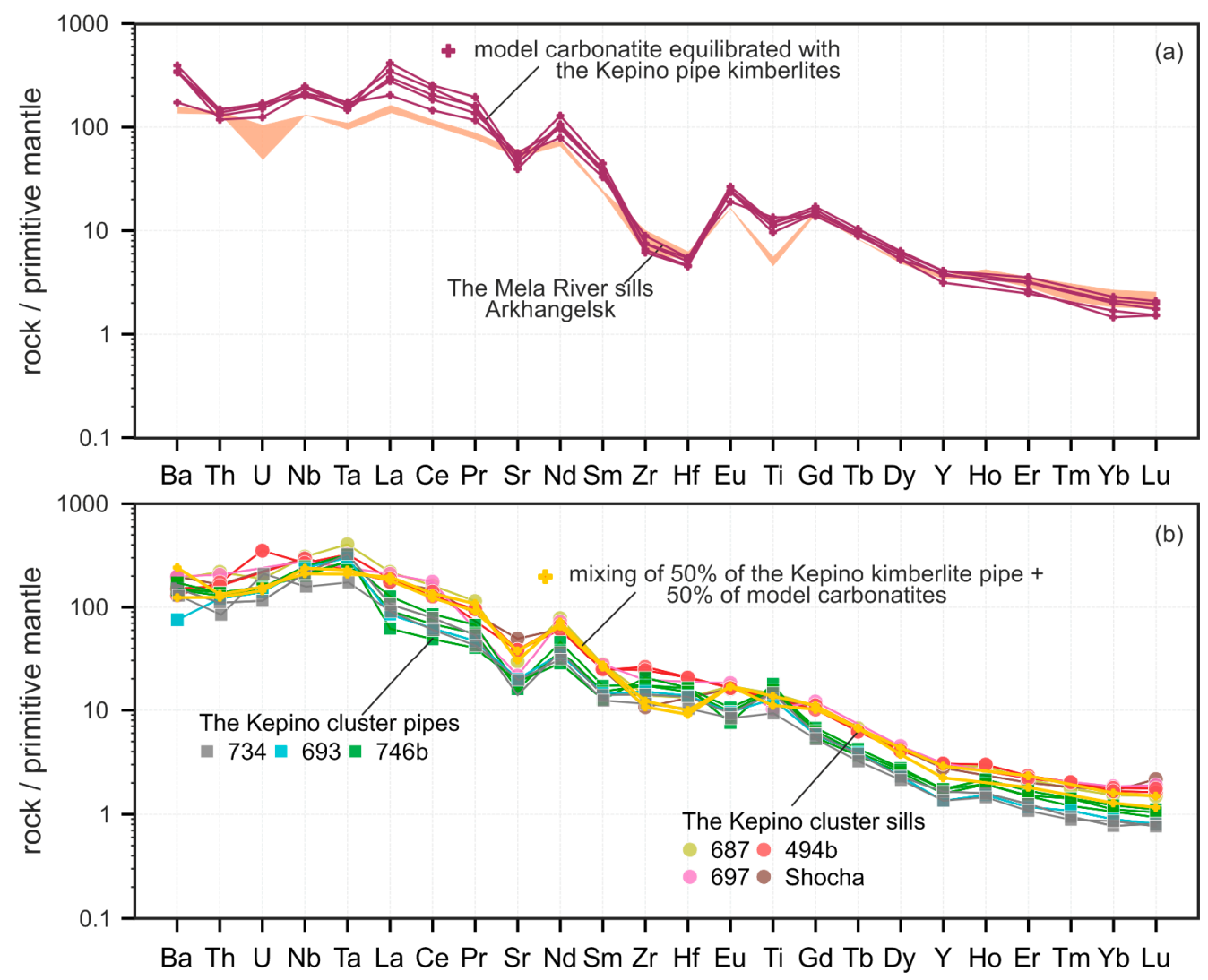

Figure 14. Trace element abundances for the Mela River kimberlite-carbonatite in comparison with modeled immiscible carbonatite melts equilibrium with kimberlite of the Kepino pipes (a), and the model mixture of 50\% kimberlite of the Kepino pipes and 50\% modeled carbonatite melt in comparison with kimberlite of the Kepino sills (b). Modeled carbonatite melts are computed as immiscible with kimberlite based on $\mathrm{KDs}$ for hydrous $\mathrm{CO}_{2}$-bearing potassic system at $1.7 \mathrm{GPa}$ and $1220{ }^{\circ} \mathrm{C}[74]$.

\subsection{Increased Oxygen Fugacity in Evolved Kimberlite Magmas}

As mentioned previously, phlogopite from both Kepino pipe and sill kimberlites shows a wide compositional variation (Figures 7 and 8). $\mathrm{Al}_{2} \mathrm{O}_{3}$ - and $\mathrm{TiO}_{2}$-bearing phlogopites occur as individual microcrysts and macrocrysts within volcanoclastic units and as relict zones within large porphyroclasts grains within coherent or massive macrocrystic units. These phlogopites also overlap the composition of Ti-Cr-bearing phlogopite from the Grib kimberlites, which could be in equilibrium within kimberlitic melts at mantle depths [57], as well as the composition of phlogopite from polymict-breccia xenoliths and phlogopite antecrysts from the African kimberlites [76]. The latter could crystallise from batches of kimberlitic melt stalled in the mantle [76,77]. On the basis of these similarities, $\mathrm{Al}_{2} \mathrm{O}_{3}$ and $\mathrm{TiO}_{2}$-bearing phlogopites could be considered to be antecrysts that crystallised from kimberlitic melts at mantle depths.

Phlogopites commonly contain significant amounts of $\mathrm{Cr}_{2} \mathrm{O}_{3}$, which allows crystallisation at earlier stages of evolution of kimberlitic melts before crystallising the main volume of spinel-bearing groundmass within coherent or massive macrocrystic units. After being taken up by kimberlitic melts, these phlogopites interact with the melts, resulting in the formation of metasomatic zones within complexly zoned grains (Figure 6c). This suggests that $\mathrm{Al}_{2} \mathrm{O}_{3}$ - and $\mathrm{TiO}_{2}$-bearing phlogopites were not in equilibrium with the host kimberlitic melts from which sills formed.

As indicated by petrographic features, the studied kimberlites from sills and massive macrocrystic units within pipes contain phlogopites that crystallised from melts during the groundmass-crystallisation stage and occur as macrophenocrysts and microphenocrysts 
as well as large poikilitic grains (Figure $5 c$,d). These phlogopites trend from $\mathrm{Al}_{2} \mathrm{O}_{3}$ - and $\mathrm{TiO}_{2}$-bearing phlogopites toward tetraferriphlogopite compositions (Figures 7 and 8 ). Some grains contain thin tetraferriphlogopite overgrowths. Magmatic fractional crystallisation under increasing $f \mathrm{O}_{2}$ could explain this compositional trend, and, in this case, all Fe entering the phlogopite is in the form of $\mathrm{Fe}^{3+}$, which is consistent with increasing titanomagnetite in the spinel (Figure 10).

Mantle-derived ilmenite xenocrysts in equilibrium with kimberlitic melts [42,48] show $f \mathrm{O}_{2}$ values close to the $\mathrm{Ni}-\mathrm{NiO}$ buffer (NNO). These ilmenites have overgrowths of latestage spinel and rutile [48] that reflect increasing $f \mathrm{O}_{2}$ to $+4 \Delta \mathrm{NNO}$. Increasing $f \mathrm{O}_{2}$ could be controlled by several factors, such as crustal contamination [67] and evolution of volatiles, including a carbonate component [78]. In addition to increasing $f \mathrm{O}_{2}$, the crustal contamination would also lead to increasing $\mathrm{Si}, \mathrm{Al}$, high REEs, changing $\mathrm{Sr}-\mathrm{Nd}$-isotopic systems, and the presence of minerals such as clinopyroxene and pectolite, which are unusual for kimberlites [4,5]. In previous geochemical and isotopic studies of Kepino kimberlites, no evidence of crustal contamination for the studied rocks was mentioned $[29,36,79]$.

Increasing $f \mathrm{O}_{2}$ likely occurred through the evolution of volatiles during kimberlitic magma evolution and emplacement as sills. This is consistent with the occurrence of carbonate segregations, which are composed of calcite and dolomite (Figure 6b). A high carbonate fraction in a melt leads to Fe oxidation and preservation of relatively high $\mathrm{Mg}$ activity in spinel [62]. It produces a change in composition from chromite to magnesian ulvöspinel and magnetite, as we have observed for spinels from the Kepino kimberlites (Figure 9a). Thus, we could conclude that the phlogopite-tetraferriphlogopite trend is not only characteristic of ultramafic lamprophyres and orangeites but also is an indicator of the evolution of carbonate-bearing kimberlitic melts.

\subsection{Age Correlation of Arkhangelsk Diamond Province Magmatism and Tectonic Episodes of Caledonian Orogenic Belt}

A recent study of $\mathrm{Rb}-\mathrm{Sr}$-isotopic ages of phlogopite from kimberlites in ADP has shown that pipes in the Zolotica and Chernoozero clusters, as well as the Tersky Coast kimberlite, were emplaced within an age range of $380 \pm 2$ Ma to $375 \pm 2$ Ma [34]. These ages match the main episode of ultramafic alkaline magmatism with carbonatite formation in the KACP massifs (e.g., [43,80]). In contrast, Kepino cluster kimberlites were emplaced earlier ( $397.3 \pm 1.2 \mathrm{Ma})$, prior to the majority of the ADP kimberlites and the KACP massifs.

A gap in emplacement ages between the Kepino kimberlites and the majority of the ADP kimberlites is supported by geological evidence concerning the Kepino: a mature lateritic profile is exclusively characteristic of the Kepino cluster and has not been observed for pipes in the Zolotica and Chernoozero clusters. Additionally, abundant xenoliths of the Cambrian and Ordovician sedimentary rocks are characteristic of the Kepino kimberlite exclusively; they are notably absent in other ADP kimberlite clusters.

The lack of early Paleozoic country-rock xenoliths and lateritic profiles shows that the early Paleozoic sedimentary sequence covered by the Devonian weathering crust was eroded after the Kepino kimberlite was emplaced and prior to the main pulse of ADP kimberlite. Based on isotopic age data for ADP kimberlite, the time lag is estimated to have been $\sim 20$ m.y.

The ancient age of the Kepino kimberlites indicates an early stage of ADP formation that was simultaneous with the early stage of $\mathrm{KACP}$, during which the alkaline volcanic rocks of Khibiny and Lovozero calderas; the Kurga alkaline massif ( $404 \pm 10 \mathrm{Ma}$ by $\mathrm{Rb}-\mathrm{Sr}$ isochron; $387 \pm 7 \mathrm{Ma}$ by U-Pb zircon); and numerous dolerite dykes of the Pechenga, Barents Sea, and Eastern Kola swarms (from $393 \pm 5$ to $371 \pm 2.5 \mathrm{Ma}$ ) were emplaced [81]. The early-stage magmatism was confined predominantly to the eastern parts of the KACP and ADP (Figure 1).

The significant time interval during which the magmatism in the KACP and ADP occurred is not consistent with the plume (mantle-upwelling) model of KACP origin e.g., [82-85]. Magmatic activity linked to the arrival of mantle plumes at the base of the lithosphere has a short duration, often $<5$ million years (e.g., [86] and references therein). 
The $>20$ Ma age gap between the Kepino kimberlites and the KACP magmatism termination is hardly interpreted as a plume-induced magmatic event. To investigate whether any other tectonic events (e.g., continental breakup, changes in direction, and speed of plate motion) controlled the early stage of ADP formation, we considered the Late Devonian tectonothermal episodes within the northern and northeastern East Europe Platform.

Related to the closure of the Iapetus Ocean, the Caledonian orogeny evolved and resulted in the Baltica-Laurentia collision in the Silurian-Devonian $([87,88]$ and references therein). An effect of decompression melting associated with far-field stress on ADP magmatism has not been investigated in detail, but the suggestion that the Caledonian orogenic events could have been the main driver of KACP magmatism was earlier proposed by A.A. Kukharenko [89]. Recent advances in our understanding of the Caledonian orogeny and in the precise dating of tectonic events provide an opportunity to compare different episodes of the orogeny with episodes of kimberlite magmatism in the ADP. The main episode of the Baltica-Laurentia convergence occurred between $438 \pm 2$ and $431 \pm 3 \mathrm{Ma}([90,91]$ and references therein). The switch from plate convergence to divergence and eduction at 410-405 Ma has also been proposed [88,91]. Subsequent post-orogenic evolution marked by exhumation of the deep crustal complexes and the development of shear zones and sedimentary basins took place $\sim 400-375 \mathrm{Ma}[91,92]$. Another researcher suggested an early post-orogenic stage at 405-395 $\mathrm{Ma}$ (when the collapse of orogeny roots began and simultaneously formed collapse basins with crustal thinning) and a late-stage at 395-375 Ma (when block rotations and extensive Devonian basins formation dominated) [88].

The age of Kepino kimberlite cluster emplacement (397 Ma) is within the early stage (405-395 Ma) of the Caledonian post-orogenic evolution. The ADP and KACP kimberlite and alkaline magmatism episodes that occurred $\sim 380-375 \mathrm{Ma}$ are simultaneous with the late Caledonian post-orogenic stage. In general, extensive alkaline magmatism (including ultramafic) in the eastern Baltic Shield is synchronous with the post-orogenic extension in the Caledonian orogenic belt, and magmatic pulses coincided with episodes of tectonic reorganisation during post-orogenic evolution. The location of the CACP and the ADP-in parallel to, and no more than $500-800 \mathrm{~km}$ from, the Caledonian orogenic belt (Figure 15) and age correlation of orogenic events and alkaline and kimberlite magmatism allow us to suggest that this magmatism can be triggered by Caledonian orogeny.

\subsection{Evolution of Kepino Kimberlite Magmas}

Modeling (presented in Section 5.2) has shown that both sill and pipe melt compositions were transitional to carbonatite melts in the shallow crust. We conclude that the Kepino sill and pipe kimberlites originated from similar but different batches of kimberlite magma on the basis of the gap in the timing of the sills and pipes emplacement (per geological observations); differences in mineralogy (mainly phlogopite) between the kimberlite sills and pipes and some specific geochemical differences (e.g., the LILE, Zr, and Hf anomalies). These differences are despite the good match between the sills kimberlite and the modeled mixture of pipes kimberlite with carbonatite melt.

Initially, all the magma batches may have come from a single unique chamber, as indicated by relics of phlogopite, ilmenite, and garnet. On the basis of pressure-temperature for Mg-ilmenite replacement by spinel and perovskite in the Kepino kimberlite [48], we suggest that this chamber was in the shallow mantle, likely at the mantle-crust boundary.

A magma first stagnated in the chamber and then fractionated and evolved to a more carbonate-rich composition. It is possible that the chamber periodically was filled with fresh kimberlite magma batches. Separate magma batches, variously evolved, sequentially left the chamber at moments when the local stress field was favourable, and formed kimberlite dykes.

Local stress variations stopped kimberlite-dyke propagation. The high content of the carbonate component ensured low viscosity of the kimberlite magma, which allowed fractures to be filled as fine interlayers or sills. The sill kimberlite preserved an evolved 
carbonate-rich melt. Low pressure led to decreasing carbonate-fluid saturation in the kimberlite melt and fluid exsolution, forming ocelli, segregations, etc.

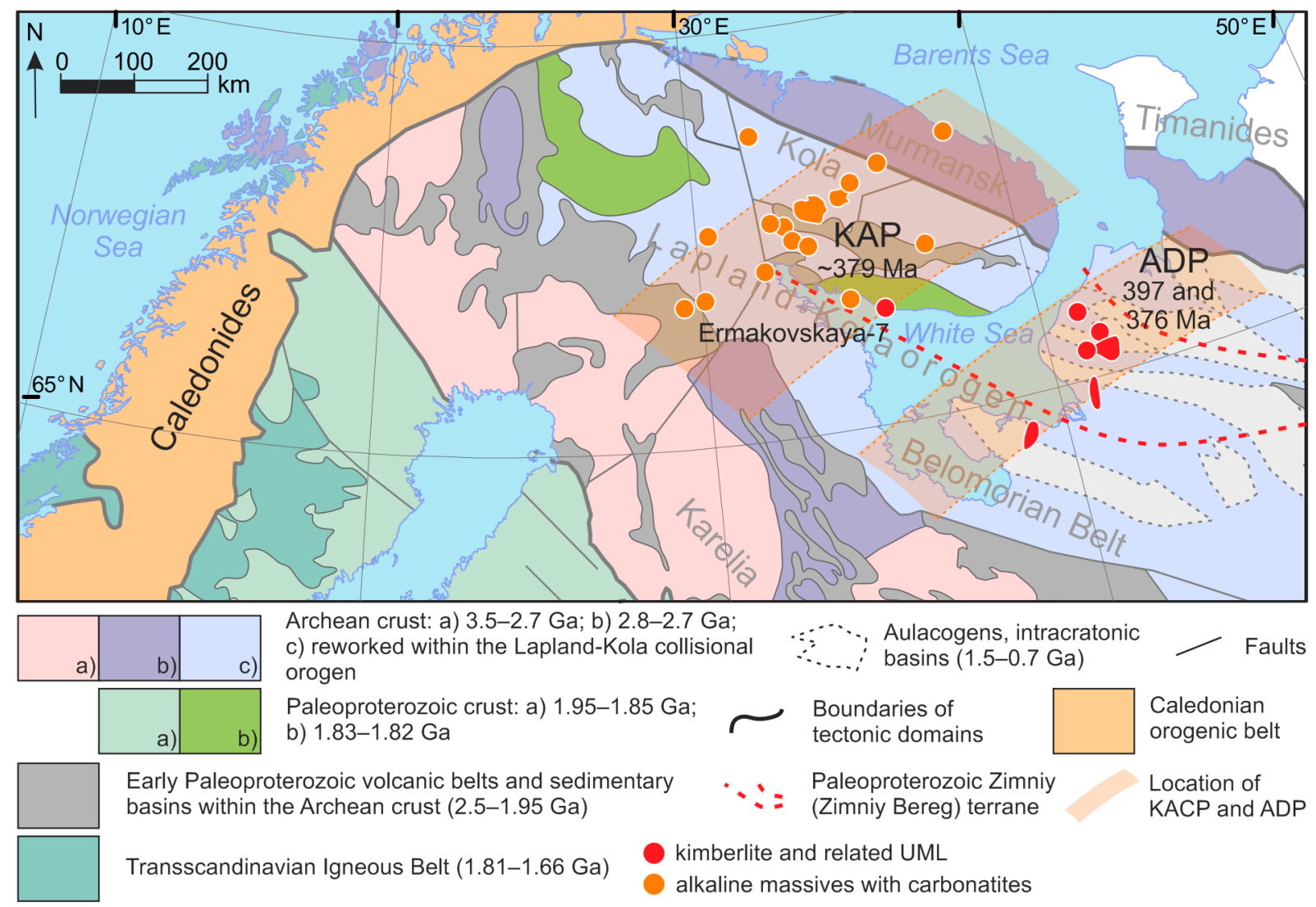

Figure 15. The Precambrian crust of Fennoscandia comprises an Archean part in the northeast and a Proterozoic part in the southwest after [47] with the position of alkaline-ultramafic magmatism of ADP and KACP as well as the position of the Caledonian orogenic belt.

Then, the local stress had changed and did not impede the kimberlite dyke from reaching the surface. Explosions during the emplacement of the pipes resulted in degassing and loss of the carbonate component. Kimberlite magma that formed pipes seems to have been less fractionated than the sill kimberlite. Evacuation from the magma chamber to form a batch from which sills are emplaced could have been simultaneous with the segregation of a new batch in the chamber.

In the subsequent magmatic pulse, this batch may form pipes. This is consistent with similar evolution trends from Al-bearing phlogopite towards tetraferriphlogopite for phlogopite (Figure 7) as well as chromite to titanomagnetite evolution trends for spinel (Figures 9 and 10) for both kimberlitic sills and pipes.

Recently a point of view that the origin of the kimberlites may not be linked to plume activity has found much support (e.g., [93-97] and references therein). Zhang et al. [96] have indicated a temporal and spatial correlation of the continental-scale kimberlite magmatic belt of the North American continent (the central Cretaceous kimberlite corridor, including kimberlites of the Somerset Island, Saskatchewan, Kansas) with the parallel and coeval Omineca magmatic belt in the Cordilleran orogen. They have demonstrated that ocean closure and entry of continental lithosphere into the trench result in continent plate flexure in response to the attempted to continue subduction. The kimberlite magmatism occurred within the tensile stress domain, which extends from 400 to $1200 \mathrm{~km}$ from the trench inward to the subducting lower plate. Tappe et al. [97] have demonstrated that the Premier kimberlite pipe was coeval with the Mesoproterozoic subduction and collision events along 
the southern Kaapvaal craton margin. They point out that far-field stress linked with orogeny created a pathway through the cratonic lithosphere for kimberlite melts.

\section{Conclusions}

The ancient age of the Kepino cluster kimberlite compared to the Grib kimberlite and other ADP kimberlite clusters indicate that the province did not form in a single magmatic episode. At least two stages of the ADP formation should be assumed. Difference emplacement styles of kimberlite bodies of early and late stages (sills vs pipes) allow us to suggest that change in local stress has occurred between the stages due to far-field stress related to the Caledonian orogeny.

The main feature of the first stage magmatism within the ADP is the widespread distribution of sills derived from evolved kimberlite. On the one hand, the common occurrence of pipes and sills is typical of large kimberlite provinces. However, kimberlitic sills have not been investigated among the ADP diamondiferous kimberlites of the second magmatic stage $[29,36]$.

The wide variation in mineral composition (primarily phlogopite and spinel) and the abundant carbonate in the studied kimberlites allow us to study the magmatic evolution of the kimberlitic melts during the formation of both sills and massive macrocrystic kimberlite within kimberlite pipes. The evolution of kimberlitic melts reflects an increase of $f \mathrm{O}_{2}$ and the exsolved fluid phase that formed ocelli, segregations, etc. These processes were accompanied by a compositional evolution of primary Al- and Ti-bearing phlogopite toward tetraferriphlogopite (Al depletion and Fe enrichment) and spinel in transition through magmatic chromite, MUM, and titanomagnetite compositional trends, which are typical of minerals from evolved kimberlite $[13,15,67,70]$ and ultramafic alkaline rocks such as aillikites and orangeites $[4,53,59,60]$. On the one hand, we found compositional similarities with minerals that form related kimberlite rocks, which is consistent with the assumption that mineral compositions alone did not suffice for mineralogical-genetic classification schemes for volatile-rich ultramafic rocks [15]; on the other hand, our work suggests that different types of volatile-rich ultramafic alkaline rocks have similar evolutionary processes of melts.

In contrast to the sill kimberlites, kimberlites of the Kepino pipes have low carbonate content. The trace element modeling shows that sill-forming kimberlitic melts could be present as a mixture of 50\% kimberlitic melts of the Kepino pipes and 50\% modeled carbonatitic melts. This suggests that the Kepino sills and pipes originated from similar primary kimberlitic melts, which could be transitional to carbonatite melts in the shallow crust. The lower carbonate amount within kimberlitic pipes could reflect processes of fluid degassing and loss during an explosive emplacement of the pipes.

Supplementary Materials: The following are available online at https://www.mdpi.com/article/ 10.3390/min11050540/s1, Figures S1-S10: Bivariate plots for the phlogopite from the Kepino kimberlite pipes and sills, Figure S11: Bivariate plots for ilmenite from the Kepino cluster kimberlite (sample 688), Figure S12: Petrographical position of phlogopite separated for isotopic studies (sample 697). Table S1: Representative major element composition of phlogopite from the Kepino cluster kimberlites, Table S2: Representative major element composition of phlogopite from the Zolotica cluster kimberlites and the Ermakovskaya-7 evolved kimberlite pipe, Kola Peninsula, Table S3: Representative major element composition of spinel from the Kepino cluster kimberlites, Table S4: Representative major and trace element composition of whole-rock samples of the kimberlite and kimberlite-related rocks of the ADP and the Ermakovskaya-7 evolved kimberlite pipe, Kola Peninsula, Table S5: Computed theoretical conjugate carbonatite compositions for the melt of the Kepino pipes based on experimental distribution coefficients for major and trace elements in natural hydrous $\mathrm{CO}_{2}$-bearing potassic compositions.

Author Contributions: Conceptualization, A.V.K., A.A.N. and L.V.S.; methodology and EPMA analytics E.V.K.; isotopic analytics Y.O.L., geology and samples, V.V.T.; investigation, A.V.K., A.A.N. and L.V.S.; writing—original draft preparation, A.V.K., A.A.N., L.V.S.; writing-review and editing, 
A.V.K., A.A.N.; visualization, A.V.K., A.A.N. All authors have read and agreed to the published version of the manuscript.

Funding: This research was funded by the Russian Science Foundation, project no. 19-17-00024.

Data Availability Statement: Not Applicable.

Acknowledgments: We are grateful to I.S. Sagaidak, and other colleagues from the Northwestern Regional Fund of Geological Information, Arkhangelsk, for permission and assistance in kimberlite sampling; the corporate management of the Severalmaz OJSC and personally A.S. Galkin, I.S. Zezin for permission to collect kimberlite samples of Arkhangelsk kimberlites and assistance in this. We are grateful to Academic Editor Paolo Nimis and four anonymous reviewers for their constructive comments and reviews. We thank Nikola Burazer for the efficient editorial handling.

Conflicts of Interest: The authors declare no conflict of interest.

\section{References}

1. Mitchell, R.H.; Giuliani, A.; O'Brien, H. What is a Kimberlite? Petrology and mineralogy of hypabyssal kimberlites. Elements 2019, 15, 381-386. [CrossRef]

2. Giuliani, A.; Pearson, D.G.; Soltys, A.; Dalton, H.; Phillips, D.; Foley, S.F.; Lim, E.; Goemann, K.; Griffin, W.L.; Mitchell, R.H.; et al. Kimberlite genesis from a common carbonate-rich primary melt modified by lithospheric mantle assimilation. Sci. Adv. 2020, 6, eaaz0424. [CrossRef] [PubMed]

3. Mitchell, R.H. Kimberlites: Mineralogy, Geochemistry, and Petrology; Plenum Press: New York, NY, USA, 1986; ISBN 978-1-4899-0570-3.

4. Mitchell, R.H. Kimberlites, Orangeites, and Related Rocks; Springer US: Boston, MA, USA, 1995; ISBN 978-1-4613-5822-0.

5. Zurevinski, S.E.; Mitchell, R.H. Highly evolved hypabyssal kimberlite sills from Wemindji, Quebec, Canada: Insights into the process of flow differentiation in kimberlite magmas. Contrib. Mineral. Petrol. 2011, 161, 765-776. [CrossRef]

6. Dawson, J.B.; Hawthorne, J.B. Magmatic sedimentation and carbonatitic differentiation in kimberlite sills at Benfontein, South Africa. J. Geol. Soc. Lond. 1973, 129, 61-85. [CrossRef]

7. White, J.L.; Sparks, R.S.J.; Bailey, K.; Barnett, W.P.; Field, M.; Windsor, L. Kimberlite sills and dykes associated with the Wesselton kimberlite pipe, Kimberley, South Africa. S. Afr. J. Geol. 2012, 115, 1-32. [CrossRef]

8. Pervov, V.A.; Larchenko, V.A.; Stepanov, V.P.; Minchenko, G.V.; Kechick, I.A.; Bogomolov, E.S.; Sergeev, S.A. Kimberlite sills along the Mela River (Arkhangelsk diamond province): Age, mineral and whole-rock composition. In Diamond Geology-Present and Future (Geologists for the 50th Anniversary of Mirny and the Diamond Mining Industry of Russia); VSU: Voronezh, Russia, 2005; pp. 558-570. (In Russian)

9. Kjarsgaard, B.A. Kimberlite Diamond Deposits. In Mineral Deposits of Canada: A Synthesis of Major Deposit Types, District Metallogeny, the Evolution of Geological Provinces, and Exploration Methods; Goodfellow, W.D., Ed.; Geological Association of Canada, Mineral Deposits Division, Special Publication: St. John's, NL, Canada, 2007; pp. 245-272.

10. Dawson, J.B. Kimberlites and Their Xenoliths; Wyllie, P.J., Ed.; Minerals and Rocks; Springer: Berlin/Heidelberg, Germany, 1980; Volume 15, ISBN 978-3-642-67744-1.

11. Howarth, G.H.; Taylor, L.A. Multi-stage kimberlite evolution tracked in zoned olivine from the Benfontein sill, South Africa. Lithos 2016, 262, 384-397. [CrossRef]

12. Mitchell, R.H. Petrology of hypabyssal kimberlites: Relevance to primary magma compositions. J. Volcanol. Geotherm. Res. 2008, 174, 1-8. [CrossRef]

13. Shee, S. The Petrology of the Wesselton Kimberlite Sills, Kimberley, Cape Province, South Africa. In Proceedings of the Fifth Intemational Kmberlite Conference THE, Araxa, Brazil, 18 June-4 July 1994; pp. 98-114.

14. Mitchell, R.H. Potassic alkaline rocks: Leucitites, lamproites, and kimberlites. Ref. Modul. Earth Syst. Environ. Sci. 2020, 1-25. [CrossRef]

15. Dongre, A.; Tappe, S. Kimberlite and carbonatite dykes within the Premier diatreme root (Cullinan Diamond Mine, South Africa): New insights to mineralogical-genetic classifications and magma $\mathrm{CO}_{2}$ degassing. Lithos 2019, 338-339, 155-173. [CrossRef]

16. Creaser, R.A.; Grütter, H.; Carlson, J.; Crawford, B. Macrocrystal phlogopite Rb-Sr dates for the Ekati property kimberlites, Slave Province, Canada: Evidence for multiple intrusive episodes in the Paleocene and Eocene. Lithos 2004, 76, 399-414. [CrossRef]

17. Sarkar, C.; Heaman, L.M.; Pearson, D.G. Duration and periodicity of kimberlite volcanic activity in the Lac de Gras kimberlite field, Canada and some recommendations for kimberlite geochronology. Lithos 2015, 218-219, 155-166. [CrossRef]

18. Heaman, L. The timing of kimberlite magmatism in North America: Implications for global kimberlite genesis and diamond exploration. Lithos 2003, 71, 153-184. [CrossRef]

19. Tappe, S.; Dongre, A.; Liu, C.Z.; Wu, F.Y. "Premier" evidence for prolonged kimberlite pipe formation and its influence on diamond transport from deep Earth. Geology 2018, 46, 843-846. [CrossRef]

20. Ranger, I.M.; Heaman, L.M.; Pearson, D.G.; Muntener, C.; Zhuk, V. Punctuated, long-lived emplacement history of the Renard 2 kimberlite, Canada, revealed by new high precision U-Pb groundmass perovskite dating. Mineral. Petrol. 2018, 112, 639-651. [CrossRef] 
21. Kostrovitsky, S.I.; Morikiyo, T.; Serov, I.V.; Yakovlev, D.A.; Amirzhanov, A.A. Isotope-geochemical systematics of kimberlites and related rocks from the Siberian Platform. Russ. Geol. Geophys. 2007, 48, 272-290. [CrossRef]

22. Kostrovitsky, S.I.; Skuzovatov, S.Y.; Yakovlev, D.A.; Sun, J.; Nasdala, L.; Wu, F.-Y. Age of the Siberian craton crust beneath the northern kimberlite fields: Insights to the craton evolution. Gondwana Res. 2016. [CrossRef]

23. Sobolev, N.V.; Sobolev, A.V.; Tomilenko, A.A.; Kuz'min, D.V.; Grakhanov, S.A.; Batanova, V.G.; Logvinova, A.M.; Bul'bak, T.A.; Kostrovitskii, S.I.; Yakovlev, D.A.; et al. Prospects of search for diamondiferous kimberlites in the northeastern Siberian Platform. Russ. Geol. Geophys. 2018, 59, 1365-1379. [CrossRef]

24. Agashev, A.M.; Pokhilenko, N.P.; Tolstov, A.V.; Polyanichko, V.V.; Malkovets, V.G.; Sobolev, N.V. New age data on kimberlites from the Yakutian diamondiferous province. Dokl. Akad. Nauk. SSSR Earth Sci. Sect. 2004, 399, 1142-1145.

25. Kargin, A.V.; Nosova, A.A.; Postnikov, A.V.; Chugaev, A.V.; Postnikova, O.V.; Popova, L.P.; Poshibaev, V.V.; Sazonova, L.V.; Dokuchaev, A.Y.; Smirnova, M.D. Devonian ultramafic lamprophyre in the Irkineeva-Chadobets trough in the southwest of the Siberian Platform: Age, composition, and implications for diamond potential prediction. Geol. Ore Depos. 2016, 58, $383-403$. [CrossRef]

26. Nosova, A.A.; Kargin, A.V.; Sazonova, L.V.; Dubinina, E.O.; Chugaev, A.V.; Lebedeva, N.M.; Yudin, D.S.; Larionova, Y.O.; Abersteiner, A.; Gareev, B.I.; et al. Sr-Nd-Pb isotopic systematic and geochronology of ultramafic alkaline magmatism of the southwestern margin of the Siberian Craton: Metasomatism of the sub-continental lithospheric mantle related to subduction and plume events. Lithos 2020, 364-365, 105509. [CrossRef]

27. Sun, J.; Liu, C.Z.; Tappe, S.; Kostrovitsky, S.I.; Wu, F.Y.; Yakovlev, D.; Yang, Y.H.; Yang, J.H. Repeated kimberlite magmatism beneath Yakutia and its relationship to Siberian flood volcanism: Insights from in situ U-Pb and Sr-Nd perovskite isotope analysis. Earth Planet. Sci. Lett. 2014, 404, 283-295. [CrossRef]

28. Zaitsev, A.I.; Smelov, A.P. Isotopic Geochronology of the Kimberlite Rocks of the Yakutsk Province; Shkodzinskii, V., Ed.; IGABM SO RAN: Yakutsk, Russia, 2010. (In Russian)

29. Mahotkin, I.L.; Gibson, S.A.; Thompson, R.N.; Zhuravlev, D.Z.; Zherdev, P.U. Late devonian diamondiferous kimberlite and alkaline picrite (Proto-kimberlite?) magmatism in the Arkhangelsk Region, NW Russia. J. Petrol. 2000, 41, 201-227. [CrossRef]

30. Tretyachenko, V.V.V.; Garanin, V.K.; Bovkun, A.V.; Garanin, K.V.K.V. Formational typification of early-hercynian volcanic complexes in Archangelsk kimberlite-picrite province. In Proceedings of the Alkaline Magmatism of the Earth and Related Strategic Metal Deposits, Proceedings of XXXII International Conference, Moscow, Russia, 7-14 August 2015; Kogarko, L.N., Ed.; GEOKHI RAS: Moscow, Russia, 2015; pp. 133-135.

31. Tretyachenko, V.V. Lithofacies characteristics and paleogeographic conditions of the Early Carboniferous transitional reservoirs of the Zimnii Bereg diamond district. In Problems of Prediction and Search for Diamond Deposits at the Closed; YaNTs SO RAN: Yakutsk, Russia, 2008; pp. 125-131. (In Russian)

32. Golovin, N.N. Geological Structure, Mineral Composition and Formation Conditions of Alkaline-Ultrabasic Rocks of the Kepinsky Area (Arkhangelsk Diamondiferous Province); Lomonosov Moscow State University: Moscow, Russia, 2003. (In Russian)

33. Kononova, V.A.; Golubeva, Y.Y.; Bogatikov, O.A.; Kargin, A.V. Diamond resource potential of kimberlites from the Zimny Bereg field, Arkhangel'sk oblast. Geol. Ore Depos. 2007, 49, 421-441. [CrossRef]

34. Larionova, Y.O.; Sazonova, L.V.; Lebedeva, N.M.; Nosova, A.A.; Tretyachenko, V.V.; Kargin, A.V. Kimberlite age in the Arkhangelsk Province, Russia: Isotopic Geochronologic Rb-Sr and 40Ar/39Ar and mineralogical data on phlogopite. Petrology 2016, 24, 562-593. [CrossRef]

35. Beard, A.D.; Downes, H.; Hegner, E.; Sablukov, S.M. Geochemistry and mineralogy of kimberlites from the Arkhangelsk Region, NW Russia: Evidence for transitional kimberlite magma types. Lithos 2000, 51, 47-73. [CrossRef]

36. Parsadanyan, K.S.; Kononova, V.A.; Bogatikov, O.A. Sources of heterogeneous magmatism of the Arkhangelsk diamondiferous province. Petrology 1996, 4, 460-479.

37. Bogatikov, O.A.; Kononova, V.A.; Nosova, A.A.; Kargin, A.V. Polygenetic sources of kimberlites, magma composition, and diamond potential exemplified by the East European and Siberian cratons. Petrology 2009, 17, 606-625. [CrossRef]

38. Sablukov, S.M.; Sablukova, L.I.; Shavyrina, M.V. Mantle xenoliths from the Zimnii bereg kimberlite deposits of rounded diamonds, Arkhangelsk diamondiferous province. Petrology 2000, 8, 466-494.

39. Kononova, V.A.; Bogatikov, O.A.; Kondrashov, I.A. Kimberlites and lamproites: Criteria for similarity and differences. Petrology 2011, 19, 34-54. [CrossRef]

40. Sablukov, S.M.; Sablukova, L.I. Asthenospheric effect on the mantle substrate and diversity of kimberlite rocks in Zimni Bereg (Arkhangelsk province). In Proceedings of the 9th International Kimberlite Conference, Frankfurt, Germany, 10-15 August 2008; p. 9IKC-A-00162.

41. Golubev, Y.K.; Prusakova, N.A.; Golubeva, Y.Y. Kepino kimberlite, Arkhangelsk region. Ores Met. 2010, 1, 38-44. (In Russian)

42. Kargin, A.V.; Nosova, A.A.; Sazonova, L.V.; Peresetskaya, E.V.; Golubeva, Y.Y.; Lebedeva, N.M.; Tretyachenko, V.V.; Khvostikov, V.A.; Burmii, Z.P.; Burmii, J.P. Ilmenite from the Arkhangelsk Diamond Province, Russia: Composition, origin and indicator of diamondiferous Kimberlites. Petrology 2020, 28, 315-337. [CrossRef]

43. Arzamastsev, A.A.; Wu, F.-Y. U-Pb geochronology and $\mathrm{Sr}-\mathrm{Nd}$ isotopic systematics of minerals from the ultrabasic-alkaline massifs of the Kola province. Petrology 2014, 22, 462-479. [CrossRef] 
44. Kargin, A.V.; Sazonova, L.V.; Nosova, A.A.; Pervov, V.A.; Minevrina, E.A.; Khvostikov, V.A.; Burmii, Z.P. Sheared peridotite xenolith from the V. Grib kimberlite pipe, Arkhangelsk Diamond Province, Russia: Texture, composition, and origin. Geosci. Front. 2017, 8, 653-669. [CrossRef]

45. Bogatikov, O.A.; Garanin, V.K.; Kononova, V.A.; Kudryavceva, G.P.; Vasilieva, E.R.; Verzhak, V.; Verichev, E.M.; Parsadanyan, K.S.; Posuhova, T.V. Arkhangelsk Diamond Province; Bogatikov, O.A., Ed.; MSU: Moscow, Russia, 1999; ISBN 5-211-02558-X. (In Russian)

46. Kargin, A.V.; Golubeva, Y.Y.; Kononova, V.A. Kimberlites of the Daldyn-Alakit region (Yakutia): Spatial distribution of the rocks with different chemical characteristics. Petrology 2011, 19, 496-520. [CrossRef]

47. Bogdanova, S.V.; Gorbatschev, R.; Garetsky, R.G. EUROPE I East European Craton. In Reference Module in Earth Systems and Environmental Sciences; Elsevier: Amsterdam, The Netherlands, 2016; pp. 1-18. ISBN 9780124095489.

48. Golubkova, A.B.; Nosova, A.A.; Larionova, Y.O. Mg-ilmenite megacrysts from the Arkhangelsk kimberlites, Russia: Genesis and interaction with kimberlite melt and postkimberlite fluid. Geochem. Int. 2013, 51, 353-381. [CrossRef]

49. Sablukov, S.M.; Sablukova, L.I.; Griffin, W.L. Distribution of trace elements in deep-situated minerals from kimberlite as indication of plume processes in the North of Russian Platform. In Deep-Situated Magmatizm, Its Source and Plumes; Institute of Geography SB RAS: Miass, Russia, 2009; pp. 135-170. (In Russian)

50. Sablukova, L.; Sablukov, S.; Verichev, E.; Golovin, N. Mantle Xenoliths of the Grib Pipe, Zimny Bereg Area, Russia. In Proceedings of the 8th International Kimberlite Conference, Victoria, BC, Canada, 22-27 June 2003; p. FLA_0060: 1-5.

51. Karandashev, V.K.; Khvostikov, V.A.; Nosenko, S.V.; Burmii, Z.P. Stable highly enriched isotopes in routine analysis of rocks, soils, grounds, and sediments by ICP-MS. Inorg. Mater. 2017, 53, 1432-1441. [CrossRef]

52. Steiger, R.H.; Jäger, E. Subcommission on geochronology: Convention on the use of decay constants in geo- and cosmochronology. Earth Planet. Sci. Lett. 1977, 36, 359-362. [CrossRef]

53. Tappe, S.; Foley, S.F.; Jenner, G.A.; Kjarsgaard, B.A. Integrating ultramafic lamprophyres into the IUGS classification of igneous rocks: Rationale and implications. J. Petrol. 2005, 46, 1893-1900. [CrossRef]

54. Kargin, A.V.; Golubeva, Y.Y.; Demonterova, E.I.; Koval'chuk, E.V. Petrographic-geochemical types of Triassic alkaline ultramafic rocks in the Northern Anabar province, Yakutia, Russia. Petrology 2017, 25, 535-565. [CrossRef]

55. Scott Smith, B.H.; Nowicki, T.E.; Russell, J.K.; Webb, K.J.; Mitchell, R.H.; Hetman, C.M.; Robey, J. A Glossary of Kimberlite and Related Terms; Scott-Smith Petrology Inc.: North Vancouver, BC, Canada, 2018; ISBN 978-1-7752806-0-6.

56. Bogatikov, O.A.; Larchenko, V.A.; Kononova, V.A.; Nosova, A.A.; Minchenko, G.V. New kimberlite bodies in the Zimnii Bereg field, Arkhangel'sk district: Petrography and prognostic estimates. Dokl. Earth Sci. 2008, 418, 68-72. [CrossRef]

57. Kargin, A.V.; Sazonova, L.V.; Nosova, A.A.; Lebedeva, N.M.; Kostitsyn, Y.A.; Kovalchuk, E.V.; Tretyachenko, V.V.; Tikhomirova, Y.S Phlogopite in mantle xenoliths and kimberlite from the Grib pipe, Arkhangelsk province, Russia: Evidence for multi-stage mantle metasomatism and origin of phlogopite in kimberlite. Geosci. Front. 2019, 10, 1941-1959. [CrossRef]

58. Beard, A.D.D.; Downes, H.; Hegner, E.; Sablukov, S.M.M.; Vetrin, V.R.R.; Balogh, K. Mineralogy and geochemistry of Devonian ultramafic minor intrusions of the southern Kola Peninsula, Russia: Implications for the petrogenesis of kimberlites and melilitites. Contrib. Mineral. Petrol. 1998, 130, 288-303. [CrossRef]

59. Tappe, S.; Foley, S.F.; Jenner, G.A.; Heaman, L.M.; Kjarsgaard, B.A.; Romer, R.L.; Stracke, A.; Joyce, N.; Hoefs, J. Genesis of ultramafic lamprophyres and carbonatites at Aillik bay, Labrador: A consequence of incipient lithospheric thinning beneath the North Atlantic Craton. J. Petrol. 2006, 47, 1261-1315. [CrossRef]

60. Kargin, A.V.; Nosova, A.A.; Larionova, Y.O.; Kononova, V.A.; Borisovsky, S.E.; Koval'chuk, E.V.; Griboedova, I.G. Mesoproterozoic orangeites (Kimberlites II) of West Karelia: Mineralogy, geochemistry, and Sr-Nd isotope composition. Petrology 2014, 22, 151-183. [CrossRef]

61. Garanin, V.K.; Bovkun, A.V.; Garanin, K.V.; Rotman, A.Y.; Serov, I.V. Microcrystalline Oxides from Russian Kimberlites and Related Rocks; GEOS: Moscow, Russia, 2009; ISBN 978-5-89118-454-1. (In Russian)

62. Roeder, P.L.; Schulze, D.J. Crystallization of groundmass spinel in Kimberlite. J. Petrol. 2008, 49, 1473-1495. [CrossRef]

63. Moore, R.O.; Griffin, W.L.; Gurney, J.J.; Ryan, C.G.; Cousens, D.R.; Sie, S.H.; Suter, G.F. Trace element geochemistry of ilmenite megacrysts from the Monastery kimberlite, South Africa. Lithos 1992, 29, 1-18. [CrossRef]

64. Castillo-Oliver, M.; Melgarejo, J.C.; Galí, S.; Pervov, V.; Gonçalves, A.O.; Griffin, W.L.; Pearson, N.J.; O’Reilly, S.Y. Use and misuse of Mg- and Mn-rich ilmenite in diamond exploration: A petrographic and trace element approach. Lithos 2017, 292-293, 348-363. [CrossRef]

65. Fitzpayne, A.; Giuliani, A.; Phillips, D.; Hergt, J.; Woodhead, J.D.; Farquhar, J.; Fiorentini, M.L.; Drysdale, R.N.; Wu, N. Kimberlite-related metasomatism recorded in MARID and PIC mantle xenoliths. Mineral. Petrol. 2018, 1-14. [CrossRef]

66. Giuliani, A.; Kamenetsky, V.S.; Kendrick, M.A.A.; Phillips, D.; Wyatt, B.A.; Maas, R. Oxide, sulphide and carbonate minerals in a mantle polymict breccia: Metasomatism by proto-kimberlite magmas, and relationship to the kimberlite megacrystic suite. Chem. Geol. 2013, 353, 4-18. [CrossRef]

67. Dalton, H.; Giuliani, A.; O'Brien, H.; Phillips, D.; Hergt, J. The role of lithospheric heterogeneity on the composition of kimberlite magmas from a single field: The case of Kaavi-Kuopio, Finland. Lithos 2020, 354-355, 105333. [CrossRef]

68. Sun, S.-S.; McDonough, W.F. Chemical and isotopic systematics of oceanic basalts: Implications for mantle composition and processes. Geol. Soc. Lond. Spec. Publ. 1989, 42, 313-345. [CrossRef] 
69. Larchenko, V.A.; Stepanov, V.P.; Minchenko, G.V.; Pervov, V.A. Age of igneous rocks, ore-bearing strata and Middle Paleozoic reservoirs of the Zimneberezhny diamondiferous region (Arkhangelsk diamondiferous province). In Diamond Geology—Present and Future (Geologists for the 50th Anniversary of Mirny and the Diamond Mining Industry of Russia); VSU: Voronezh, Russia, 2005; pp. 322-347. (In Russian)

70. Apter, D.B.; Harper, F.J.; Wyatt, B.A.; Smith, B.H.S. The Geology of the Mayeng Kimberlite sill complex, South Africa. In Developments in Petrology; Elsevier: Amsterdam, The Netherlands, 1984; pp. 43-57.

71. Stamm, N.; Schmidt, M.W.; Szymanowski, D.; von Quadt, A.; Mohapi, T.; Fourie, A. Primary petrology, mineralogy and age of the Letšeng-la-Terae kimberlite (Lesotho, Southern Africa) and parental magmas of Group-I kimberlites. Contrib. Mineral. Petrol. 2018, 173, 1-25. [CrossRef]

72. Castillo-Oliver, M.; Giuliani, A.; Griffin, W.L.; O’Reilly, S.Y.; Drysdale, R.N.; Abersteiner, A.; Thomassot, E.; Li, X.H. New constraints on the source, composition, and post-emplacement modification of kimberlites from in situ C-O-Sr-isotope analyses of carbonates from the Benfontein sills (South Africa). Contrib. Mineral. Petrol. 2020, 175. [CrossRef]

73. Tappe, S.; Kjarsgaard, B.A.; Kurszlaukis, S.; Nowell, G.M.; Phillips, D. Petrology and Nd-Hf isotope geochemistry of the neoproterozoic amon Kimberlite sills, Baffin Island (Canada): Evidence for deep mantle magmatic activity linked to supercontinent cycles. J. Petrol. 2014, 55, 2003-2042. [CrossRef]

74. Martin, L.H.J.; Schmidt, M.W.; Mattsson, H.B.; Guenther, D. Element partitioning between immiscible carbonatite and silicate melts for dry and H2O-bearing systems at 1-3gpa. J. Petrol. 2013, 54, 2301-2338. [CrossRef]

75. Cooper, A.F. Petrology and petrogenesis of an intraplate alkaline lamprophyre-phonolite-carbonatite association in the Alpine Dyke Swarm, New Zealand. N. Z. J. Geol. Geophys. 2020, 63, 469-488. [CrossRef]

76. Giuliani, A.; Phillips, D.; Kamenetsky, V.S.; Goemann, K. Constraints on kimberlite ascent mechanisms revealed by phlogopite compositions in kimberlites and mantle xenoliths. Lithos 2016, 240-243, 189-201. [CrossRef]

77. Giuliani, A.; Phillips, D.; Kamenetsky, V.S.; Kendrick, M.A.; Wyatt, B.A.; Goemann, K.; Hutchinson, G. Petrogenesis of mantle polymict breccias: Insights into mantle processes coeval with kimberlite magmatism. J. Petrol. 2014, 55, 831-858. [CrossRef]

78. Whitley, S.; Halama, R.; Gertisser, R.; Preece, K.; Deegan, F.M.; Troll, V.R. Magmatic and metasomatic effects of magma-carbonate interaction recorded in calc-silicate xenoliths from Merapi volcano (Indonesia). J. Petrol. 2020, 61. [CrossRef]

79. Kononova, V.A.; Levsky, L.K.; Pervov, V.A.; Ovchinnikova, G.V.; Bogatikov, O.A. Pb-Sr-Nd isotopic systematics of mantle sources of potassic ultramafic and mafic rocks in the north of the East European platform. Petrology 2002, 10, $433-447$.

80. Stifeeva, M.V.; Salnikova, E.B.; Arzamastsev, A.A.; Kotov, A.B.; Grozdev, V.Y. Calcic garnets as a source of information on the age of ultramafic alkaline intrusions in the Kola Magmatic Province. Petrology 2020, 28, 62-72. [CrossRef]

81. Arzamastsev, A.A.; Vesolovskiy, R.V.; Travin, A.V.; Yudin, D.S.; Belyatsky, B.V. Paleozoic tholeiitic magmatism of the Kola province: Spatial distribution, age, and relation to alkaline magmatism. Petrology 2017, 25, 42-65. [CrossRef]

82. Kramm, U.; Kogarko, L.N.; Kononova, V.A.; Vartiainen, H. The kola alkaline province of the CIS and Finland: Precise RbSr ages define 380-360 Ma age range for all magmatism. Lithos 1993, 30, 33-44. [CrossRef]

83. Zartman, R.E.; Kogarko, L.N. Lead isotopic evidence for interaction between plume and lower crust during emplacement of peralkaline Lovozero rocks and related rare-metal deposits, East Fennoscandia, Kola Peninsula, Russia. Contrib. Mineral. Petrol. 2017, 172, 32. [CrossRef]

84. Tolstikhin, I.N.; Kamensky, I.L.; Marty, B.; Nivin, V.A.; Vetrin, V.R.; Balaganskaya, E.G.; Ikorsky, S.V.; Gannibal, M.A.; Weiss, D.; Verhulst, A.; et al. Rare gas isotopes and parent trace elements in ultrabasic-alkaline-carbonatite complexes, Kola Peninsula: Identification of lower mantle plume component. Geochim. Cosmochim. Acta 2002, 66, 881-901. [CrossRef]

85. Arzamastsev, A.A.; Bea, F.; Arzamastseva, L.V.; Montero, P. Kola alkaline province in the Paleozoic: Evaluation of primary mantle magma composition and magma generation conditions. Russ. J. Earth Sci. 2001, 3, 3-24. [CrossRef]

86. Ernst, R.E. Large Igneous Provinces. In Encyclopedia of Geology; Elsevier: Amsterdam, The Netherlands, $2021 ;$ pp. 60-68.

87. Roberts, D. The Scandinavian Caledonides: Event chronology, palaeogeographic settings and likely modern analogues. Tectonophysics 2003, 365, 283-299. [CrossRef]

88. Wiest, J.D.; Jacobs, J.; Fossen, H.; Ganerød, M.; Osmundsen, P.T. Segmentation of the Caledonian orogenic infrastructure and exhumation of the Western Gneiss Region during transtensional collapse. J. Geol. Soc. Lond. 2020, jgs2020-199. [CrossRef]

89. Kukharenko, A.A.; Bulakh, A.G.; Il'insky, G.A. Metallogenic features of alkaline formations of the eastern Baltic Shield. Tr. Leningr. Ob-Va Estestvoispyt. 1971, 72, 280. (In Russian)

90. Andreasson, P.G.; Gee, D.G.; Whitehouse, M.J.; Schoberg, H. Subduction-flip during Iapetus Ocean closure and Baltica-Laurentia collision, Scandinavian Caledonides. Terra Nov. 2003, 15, 362-369. [CrossRef]

91. Spengler, D.; Brueckner, H.K.; van Roermund, H.L.M.; Drury, M.R.; Mason, P.R.D. Long-lived, cold burial of Baltica to 200 km depth. Earth Planet. Sci. Lett. 2009, 281, 27-35. [CrossRef]

92. Fossen, H. Extensional tectonics in the Caledonides: Synorogenic or postorogenic? Tectonics 2000, 19, 213-224. [CrossRef]

93. Jelsma, H.; Barnett, W.; Richards, S.; Lister, G. Tectonic setting of kimberlites. Lithos 2009, 112, 155-165. [CrossRef]

94. Kjarsgaard, B.A.; Heaman, L.M.; Sarkar, C.; Pearson, D.G. The North America mid-Cretaceous kimberlite corridor: Wet, edgedriven decompression melting of an OIB-type deep mantle source. Geochem. Geophys. Geosyst. 2017, 18, 2727-2747. [CrossRef]

95. Pandey, A.; Rao, N.V.C. Supercontinent transition as a trigger for $\sim 1.1$ Gyr diamondiferous kimberlites and related magmatism in India. Lithos 2020, 370-371, 105620. [CrossRef] 
96. Zhang, W.; Johnston, S.T.; Currie, C.A. Kimberlite magmatism induced by west-dipping subduction of the North American plate. Geology 2019, 47, 395-398. [CrossRef]

97. Tappe, S.; Stracke, A.; van Acken, D.; Strauss, H.; Luguet, A. Origins of kimberlites and carbonatites during continental collision-Insights beyond decoupled Nd-Hf isotopes. Earth Sci. Rev. 2020, 208, 103287. [CrossRef] 